\title{
ANTIOXIDANT AND ANTIRADICAL ACTIVITY OF GREEN TEA (Camellia sinensis) AQUEOUS EXTRACT AND ITS CAPABILITY TO RETARDATION OF RATS LIVER CIRRHOSIS
}

\author{
Bakr $^{*}$ S.M.A., Kishk ${ }^{1}$ Y.F.M., Soad A. Ali ${ }^{2}$ and Elnawawy ${ }^{1}$ M.A. \\ 1- Food Sci. Dept., Fac. of Agric., Ain Shams Univ., P.O Box 68, Hadayek Shubra 11241, Cairo, \\ Egypt \\ 2- Cairo University Hospitals, Kasr El-Aini, Cairo, Egypt
}

[178]

*Corresponding author: SaiedMbakr@gmail.com

Received 14 June, 2018

Accepted 30 July, 2018

\section{ABSTRACT}

The aim of the present study was to optimize the extraction conditions of green tea aqueous extract [green tea concentration $(G)$ and extraction temperature $(T)$ ]. Response surface methodology was applied to determine the highest radical scavenging activity (RSA), Ferric reducing antioxidant power (FRAP) and reducing power (RP) of the prepared green tea extract. Effect of green tea aqueous extract prepared using the optimal conditions on the liver cirrhosis retardation in rats was also investigated. Two-factors central composite design was established to determine the effects of $G$ or $T$ and radical scavenging holding time as independent variables on RSA, FRAP and RP as dependent variables. The optimum $\mathrm{G}, \mathrm{T}$ and holding time with maximum RSA were $1.0 \%, 88.7^{\circ} \mathrm{C}$ for $25 \mathrm{~min}$, with a predicted RSA of $81.3 \%$ $\left(r^{2}=0.9115\right)$ compared to the BHT, which had a scavenging value of $87.4 \%$ at concentration 150 ppm and holding time 30 min The same predicted concentration and temperature obtained with the highest FRAP and RP were 2.566 and 1.687 with $r^{2} 0.9780$ and 0.9550 , respectively. The phenolic and flavonoid contents were $81.2 \mathrm{mg}$ gallic acid equivalent and $33.5 \mathrm{mg}$ quercetin equivalent per $100 \mathrm{ml}$ green tea extract. The extract prepared at optimal conditions was used for treatment of cirrhotic rats by $\mathrm{CCl}_{4}$. Insignificant $(P \geq 0.05)$ differences were observed between the green tea group and control group in obtained total protein or albumin values. Total protein and albumin were dramatically decreased in the group treated by $\mathrm{CCL}_{4}$.
The same trend was observed with studying the transaminase enzymes. Histopathological sections appeared the effect of green tea extract on the retardation of liver cirrhosis in rats.

Keywords: Green tea, Phenolics, flavonoids, Radical scavenging activity, Ferric reducing antioxidant power, Reducing power, Liver cirrhosis

\section{INTRODUCTION}

Green tea (Camellia sinensis L.) is one of the most oriental drink consumed around the world (Namal Senanayake, 2013). Recently, tea has attracted more attention due to its beneficial health effects and special flavor and taste (Zhang et al 2013). Tea can be classified into three kinds according to the level of oxidation, like green tea, oolong tea and black tea (Chan, 2011; Velayutham et al 2008). Green tea is rich in polyphenols such as (-)-catechins or (-)-flavan-3-ols including epicatechin, (-)-epigallocatechin, (-)epicatechin gallate and (-)-epigallocatechin gallate, as well as the alkaloid caffeine (Budryn et al 2013; Zielinski et al 2015). The extraction of green tea polyphenols depend on both time- and temperature (Baptista et al 1998; Shishikura and Khokhar, 2005). Due to greater extraction of polyphenols, resulting in high values of scavenging oxidative radical, as hot water is preferred for preparation of tea compared to cold water (Lin et al 2010). Green tea polyphenols can act as prooxidants by generating hydrogen peroxide (Long, et al 1999). Tea consumed because of the many 
beneficial health effects it has on human. Compared to black tea, green tea has been reported to have higher antioxidant capacity and a greater level of polyphenols (Koo and Cho, 2004). Antioxidants have shown to have multiple functional and remedial properties that include antiradical, anticarcinogenic, anti-inflammatory oxidative stress reduction, and cardio protection (Chan et al 2010).

Previous studies utilized green tea as immunostimulant by incorporating it in fish diet that can increase disease resistance, and improve survival rate, growth rate and antioxidant system (Sheikhzadeh, 2011; Kim et al 2014). Green tea consumption effects in general health and reduction of risk in severe diseases. In addition there are a trend with promising and positive results to assist the control of body weight (Vieira Senger et al 2012), protection against ultraviolet radiation (Clarke et al 2016), physical functional performance ( $\mathrm{Ng}$ et al 2014; Tomata et al 2012), oral health (Gaur et al 2014), bone health (Shen et al 2012) and other physiological effects.

Non-alcoholic fatty liver disease is considered to be the most common cause of chronic liver disease worldwide and is a multifactorial disease with a complex pathophysiology including hepatic steatosis, non-alcoholic steatohepatitis, and subsequent fibrosis, cirrhosis and hepatocellular carcinoma (Wang et al 2013; Birkenfeld et al 2014). Singal et al 2006 reveal that green tea extract significantly attenuated lipopolysaccharide induced sickness behavior as well as hepatic damage either by its antioxidant activity or by inhibiting lipopolysaccharide induced cytokine production. Studying the effect of optimization process on the potential antioxidant effect of green tea and its effect on the liver cirrhosis have a shortage. Therefore, the objective of the current study was to I) optimize the green tea concentration and extraction temperature for preparing green tea aqueous extract with high potential antioxidant and antiradical activities; II) in vivo evaluating the ability of the optimized green tea extract to retardation of the liver cirrhosis in rats.

\section{MATERIALS AND METHODS}

\section{Materials}

2,2-diphenyl-2-picrylhydrazyl radical ((DPPH'), 2,4,6-Tris (2-pyridyl)-s-triazine Synonym: 2,4,6-Tris (2-pyridyl)-s-triazine, TPTZ and methanol were purchased from Sigma, Chemicals Company. Coline, casein, vitamins, minerals, cellulose, phos- phate buffer, potassium ferricyanide, trichloroacetic acid, $\mathrm{FeCL}_{3}, \mathrm{CCL} 4, \mathrm{HCl}$ and sodium acetate anhydrous were obtained from El-Gomhouria Company for Trading Pharmaceuticals, Chemicals and Medical Supplies, Cairo, Egypt. Starch and corn oil were obtained from local market in Cairo, Egypt. The green tea (Camellia sinensis) purchased from the local market in Changsha province, China. Total Bilirubin, GPT, GOT, total protein, albumin, Alk-Phospatse and LDH were purchased from Bate Lab Company, Cairo, Egypt. , Reduced glutathione and Malondialdehyde were obtained from Bio Diagnostic Company, Al-Dokki, Giza, Egypt. Forty-eight female albino rats each weighing (Sprague Dawley strain) were obtained from Organization of Biological Products and Vaccines (Helwan Farm, Cairo, Egypt).

\section{Methods}

\section{Preparation of green tea water extract}

The green tea extracts were prepared at five concentrations of $0.25,0.5,0.75,1.0$ and $1.25 \%$ $(\mathrm{w} / \mathrm{v})$ using distilled water at four different temperatures were 40, 60, 80 and $100{ }^{\circ} \mathrm{C}$. Appropriate amount of green tea weighted in five beakers, then add $100 \mathrm{ml}$ of distilled water at different temperatures. Thereafter, leave the beakers contain the extracts until take the room temperature.

\section{Total phenolics content}

Total phenolics content was determined spectrophotometrically using the modified FolinCiocalteau colorimetric method (Eberhardt et al 2000). Mix $125 \mu \mathrm{l}$ of extract with $0.5 \mathrm{ml}$ of distilled water in a test tube; followed by addition of $125 \mu \mathrm{l}$ of Folin-Ciocalteau reagent and allowed to stand for $6 \mathrm{~min}$. Then, add $1.25 \mathrm{ml}$ of $7 \%$ sodium carbonate solution. The final volume was adjusted to $3 \mathrm{ml}$ with distilled water. Each sample was allowed to stand for $90 \mathrm{~min}$ at room temperature and the absorbance was measured at $760 \mathrm{~nm}$ using spectrophotometer Unico (made in, USA). The total phenolics content was expressed as a micrograms gallic acid equivalent/ $\mathrm{ml}$ extract (mg GAE/100 ml) by reference to the gallic acid standard calibration curve using equation (1) with $r^{2}=0.9850$

$$
Y=-0.210+4.207 X
$$

[Eq. 1] 

Extract and Its Capability to Retardation of Rats Liver Cirrhosis

\section{Total flavonoids content}

Aluminum chloride complex forming assay was used to spectrophotometrically determine the total flavonoids content of the extracts (Piyanete et al 2009). A $100 \mu \mathrm{l}$ of extract mixed with $0.5 \mathrm{ml}$ of distilled water and $100 \mu \mathrm{l}$ of $5 \%$ Sodium nitrate in a test tube. Allowed to stand the test tube for 6 minutes at room temperature. Thereafter, added $150 \mu \mathrm{l}$ of $10 \%$ Aluminum chloride and allowed to stand for 5 minutes at room temperature. Then, $200 \mu \mathrm{l}$ of $1 \mathrm{M}$ sodium hydroxide solution was added. The absorbance was measured at $510 \mathrm{~nm}$ using spectrophotometer Unico (made in, USA). The total flavonoids content was expressed as a micrograms quercetin equivalent/ml extract (mg $\mathrm{QE} / 100 \mathrm{ml}$ ) by reference to the quercetin standard calibration curve using equation (2) with $r^{2}=0.955$.

$$
Y=-0.018+2.740 X
$$

[Eq. 2]

\section{DPPH radical scavenging activity}

Radical-scavenging activity of the prepared green tea extracts was tested using spectrophotometric method (Brand-Williams et al 1995). Ten microliters of different green tea extracts, ascorbic acid or BHT solutions were added to one $\mathrm{ml}$ of methanolic DPPH solution (0.0374 $\mathrm{g} / \mathrm{l}$ methanol). The decrease in absorbance was determined at $517 \mathrm{~nm}$ during holding time from zero to $30 \mathrm{~min}$ using spectrophotometer Jenway-Model 6105 (made in, UK). The scavenged percent of DPPH in the holding was calculated according to the following equation:

$$
\text { Inhibition (\%) }=A_{\circ}-A / A_{\circ} \times 100
$$

Where $A$, was the Absorbance of control and $A$ was the Absorbance of sample.

\section{Ferric reducing antioxidant power}

Ferric Reducing Antioxidant Power (FRAP) was determined by the method of Benzie and Strain (1996). Add $3.12 \mathrm{~g} / \mathrm{l}$ distilled water to prepare 2,4,6-tripyridyl-s-triazine solution (TPTZ). To preparation ferric chloride hexahydrate ( $\mathrm{FeCl} 36 \mathrm{H} 2 \mathrm{O})$ solution mix $5.4 \mathrm{~g} / \mathrm{l}$ distilled water. Mix $2.72 \mathrm{~g}$ sodium acetate tri-hydrate / distilled water then adjusted the solution to $\mathrm{pH} 3.6$ using $\mathrm{HCl}$. The reagent prepared by mixed the previous three solution according to the ratio was $1: 1: 10$. The reagent was pipetted $(1500 \mu \mathrm{l})$ into a cuvette with subsequent addition of a $50 \mu \mathrm{l}$ tested solution. Then the absorbance was measured at $593 \mathrm{~nm}$ using spectrophotometer Jenway-Model 6105 (made in UK). The FRAP expressed as optical density.

\section{Reducing power}

The reducing power of prepared green tea extracts was determined according to the method described by Oyaizu, (1986). One $\mathrm{ml}$ of extract mixed with $2.5 \mathrm{ml}$ phosphate buffer at $\mathrm{pH} 6.6$ and $2.5 \mathrm{ml}$ potassium ferric cyanide $(1 \%)$. The mixture was incubated at $50{ }^{\circ} \mathrm{C}$ for 20 min added $2.5 \mathrm{ml}$ trichloroacetic acid (10\%) to the mixture. Then centrifuged the mixture at $3000 \mathrm{rpm}$ for $10 \mathrm{~min}$. The upper layer of solution $(2.5 \mathrm{ml})$ was mixed with 2.5 $\mathrm{ml}$ distilled water and $0.5 \mathrm{ml} \mathrm{FeCl} 3(0.1 \%)$. The absorbance was measured at $700 \mathrm{~nm}$ using spectrophotometer Jenway-Model 6105 (made in, UK). The RP expressed as optical density.

\section{Animals experiment and diets}

Forty eight adult female albino rats were housed in screen-bottomed aluminum cages in room maintained at $25 \pm 1^{\circ} \mathrm{C}$ with alternating cycles of light and dark of $12 \mathrm{~h}$; duration. The rats were fed on the control diet for seven consecutive days. Rats were randomly divided into six groups, each group contained eight rats. All group fed on the basil diet. The first group identified as negative control group (G1). The groups (2 and 3) treated by carbon tetra chloride $\left(\mathrm{CCL}_{4}\right)$ and identified as a cirrhotic groups. The $2^{\text {nd }}$ group was a positive control group (G2). The group treated by green tea extract that prepared at optimal conditions $(1.0 \%$, $88.7^{\circ} \mathrm{C}$ ) identified as a (G3). The extract given orally for the rats daily in a dose of $0.6 \mathrm{ml} / 100 \mathrm{~g}$ body weight for successive twelve weeks. Liver toxicity was induced by a weekly dose of $\mathrm{CCl}_{4}(1 \mathrm{ml} / \mathrm{kg}$ body weight) diluted with corn oil at ratio was $1: 1$ (Ehrinpreis et al 1980). The carbon tetra chloride given intraperitoneally injection to all rats except that normal control group was given corn oil. The composition of the experimental diets shown in Table (1) according to AIN-93 guidelines (Philip et al 1993). The dose calculated based on a consumption of $275 \mathrm{ml} /$ day for a $70 \mathrm{~kg}$ human as reported by Rouanet et al (2010). The changes in body weight were recorded ones every week. Blood samples also obtained from the retro-orbital plexus of the eyes from all animals of each group on 30, 60 and 90 days according to the procedure of Schermer (1967). At the end of the experiment, rats were sacrificed and organs were excised and weighed, specimen for liver was obtained and preserved in formaldehyde (10\%) for the histopathological examination. Serum was separated and the serum biochemical analyses were carried out. 
Table 1. Compositions of the basil diet (\%) and its content from mineral mixture (g) and vitamins (IU or mg)

\begin{tabular}{|c|c|c|c|c|c|}
\hline \multicolumn{2}{|c|}{ Basil diet (\%) } & \multicolumn{2}{|c|}{ Salt mixture $^{*}$} & \multicolumn{2}{|c|}{ Vitamins mixture } \\
\hline Ingredients & $\%$ & Salt & Wight (g) & Vitamin & Wight (IU or g) \\
\hline Corn starch & 60.5 & $\mathrm{CaCO}_{3}$ & 304.5 & Vit. A & $2000 I U$ \\
\hline Casein & 20 & $\mathrm{KH}_{2} \mathrm{PO}_{4}$ & 327.5 & Vit. D & $2001 U$ \\
\hline Corn oil & 10 & $\mathrm{CaHPO}_{4} .2 \mathrm{H}_{2} \mathrm{O}$ & 60.0 & Methionine & $0.5 \mathrm{mg}$ \\
\hline Cellulose & 5 & $\mathrm{MgSO}_{4} .7 \mathrm{H}_{2} \mathrm{O}$ & 103.5 & Inositol & $10 \mathrm{mg}$ \\
\hline Salt mixture $^{*}$ & 3.5 & $\mathrm{NaCL}$ & 170.0 & Niacin & $4 \mathrm{mg}$ \\
\hline Vitamin mixture & 1 & $\mathrm{Fe}\left(\mathrm{C}_{6} \mathrm{H}_{5} \mathrm{O}_{7}\right) \cdot 6 \mathrm{H}_{2} \mathrm{O}$ & 28.0 & Ca-pa ntothenate & $4 \mathrm{mg}$ \\
\hline & & & 0.81 & Riboflavin & $0.8 \mathrm{mg}$ \\
\hline & & $\mathrm{MnSO}_{4}$ & 5.12 & Thiamine & $0.5 \mathrm{mg}$ \\
\hline & & $\mathrm{ZnCL}_{2}$ & 0.25 & Pyridoxine & $0.5 \mathrm{mg}$ \\
\hline & & $\mathrm{CuSO}_{4} \cdot 5 \mathrm{H}_{2} \mathrm{O}$ & 0.31 & Folic acid & $0.2 \mathrm{mg}$ \\
\hline & & & & Cholic acid & $0.2 \mathrm{~g}$ \\
\hline & & & & Biotin & $0.4 \mathrm{mg}$ \\
\hline & & & & Vit.B12 & $0.003 \mathrm{mg}$ \\
\hline & & & & P-amino benzoic acid & $10 \mathrm{mg}$ \\
\hline & & & & Glucose & $1000 \mathrm{~g}$ \\
\hline
\end{tabular}

\section{Biochemical analyses}

Total Bilirubin in serum was estimated as described by Malloy et al (1937). Alanine aminotransferase (ALT), Aspartate aminotransferase (AST), total protein (TP), Albumin (ALB) were determined according to the method presented in Young, (1995). Spectrophotometer Clinical Chemistry Analyzer-VS10 (made in USA) was used. The protective factor calculated from serum biomarkers by divided the slop of $\mathrm{G} 2$ biomarker on each treated group biomarker. The higher slope value means the high liver damaged.

\section{Histopathological examination}

Autopsy samples taken from liver, kidney and heart of rats in different groups and fixed in $10 \%$ formol saline for twenty-four hours. Washing was done in tap water then serial dilutions of alcohol (methyl, ethyl and absolute ethyl) were used for dehydration. Specimens were cleared in xylene and embedded in paraffin at 56 degree in hot air oven for twenty-four hours. Paraffin bees wax tissue blocks were prepared for sectioning at $4 \mathrm{mi}-$ crons thickness by slidge microtome. The obtained tissue sections were collected on glass slides, deparaffinized, and stained by hematoxylin and eosin stain for routine examination through the light electric microscope (Banchroft et al 1996).

\section{Statistical analyses}

ANOVA analysis was carried out using the PROC ANOVA procedure of Statistical Analysis System (SAS, 2000). Duncan multiple ranges at $5 \%$ level of significance was used according to Duncan (1955) to compare between means. Results followed by different alphabetical letters significantly differed. Predicting individual radical scavenging activity, ferric reducing antioxidant power and reducing power $(\mathrm{Y})$ was assumed by quadratic or cubic polynomial regression models. The independent variables were green tea concentrations or preparation temperature $(X)$ to optimize the radical scavenging activity, ferric reducing antioxidant power and reducing power $(\mathrm{Y})$ used regression analysis. The models proposed for response of $Y$ as follows:

$$
\begin{aligned}
& Y=y_{0}+a x+b x^{2} \\
& Y=y_{\circ}+a x+b x^{2}+c x^{3}
\end{aligned}
$$

Where, $y_{\circ}, a, b$ and $c$ are intercept, linear, quadratic and cubic regression coefficient terms, respectively and $X$ is independent variable. Threedimension contour plot was used as a method to study the response surface of different radical scavenging activity, ferric reducing antioxidant power and reducing power $(\mathrm{Y})$ as dependent variables with green tea concentrations or preparation temperature ( $\mathrm{X}$ and $\mathrm{Z}$ ) as independent variables. 

Extract and Its Capability to Retardation of Rats Liver Cirrhosis

The response surface method was applied using Sigma Plot (2014). The model proposed for Three-dimension response surface of $Y$ was as follows:

$$
\begin{gathered}
Y=y_{0}+a x+b z+c x^{2}+d z^{2}+e x^{3}+g z^{3}+h x^{4}+i z^{4} \\
+j x^{2} z^{2}+k x^{3} z^{3}+l x^{4} z^{4} \quad \text { [Eq. 6] } \\
\text { RESULTS AND DISCUSSION }
\end{gathered}
$$

Effect of concentrations, temperatures and times on the $\mathrm{DPPH}^{\circ}$ scavenging activity

The radical scavenging activity of aqueous green tea extracts at different concentrations, times and temperatures were investigated. Radical scavenging activity at $40,60,80$ and $100^{\circ} \mathrm{C}$ were expressed as inhibition percent of DPPH and presented in Table 2. Significant $(P \leq 0.05)$ differences observed between the values of the radical scavenging activities of the concentrations or the holding times. The extract that prepared at green tea concentration of $1.25 \%$ showed the highest scavenging activity values of $83 \%$ at zero time and 85 $\%$ after holding time for $30 \mathrm{~min}$ with significant difference $(P \leq 0.05)$. Lower corresponding values of green tea extract that prepared using $0.25 \%$ green tea. The radical scavenging activity value at zero time was $40 \%$ then increased to $42 \%$ after holding time for 30 min with significant $(P \leq 0.05)$ difference. Increasing the concentration or the holding time lead to increase the radical scavenging activity. Gramza1 et al (2005) reported that antiradical activity of plant extracts is dependent on mechanisms of oxidative activity of free radicals used and the chemical structure of contained antioxidants. Significant $(P \leq 0.05)$ difference observed between the radical scavenging activity values at different green tea concentrations and holding times (Table 2). The values slightly increased more than those obtained at $40{ }^{\circ} \mathrm{C}$. It was 44 and $86 \%$ at concentrations of 0.25 and $1.25 \%$, respectively. Concerning the scavenging activity of the tested extracts, the holding time $30 \mathrm{~min}$ had significantly $(P \leq 0.05)$ the highest values at concentration $0.25 \%$ being $54 \%$. On the other hand, the holding time $20 \mathrm{~min}$ had significantly $(P \leq 0.05)$ the highest values at concentration $1.25 \%$ with value was $88 \%$. By increasing, the preparation temperature from 40 to $60{ }^{\circ} \mathrm{C}$ the radical scavenging activity was slightly increased at all tested concentrations and holding times. At the same time, significant $(P \leq 0.05)$ differences were observed between those values obtained at different holding times. It were 51 and
$76 \%$ in tested extracts prepared using 0.25 and $1.25 \%$ green tea at zero time. Increasing the holding time lead to increase the scavenging activity to the maximum value of $60 \%$ at 15 min when 0.25 $\%$ green tea concentration was used for preparing the extract. In contrary, the maximum radical scavenging activity of the extract prepared at green tea concentration of $1.25 \%$ was obtained after $30 \mathrm{~min}$ with value of $81 \%$. Generally, the radical scavenging activity of the green tea extracts negatively affected by used the temperature $80^{\circ} \mathrm{C}$ in preparation of extracts. From Table 2, the negative effect on the prepared green tea extract at high temperature $\left(100^{\circ} \mathrm{C}\right)$ was increased. The same trend was observed with decreased the radical scavenging values at all green tea concentrations and holding times. Radical scavenging activity showed nonsignificantly $(P \geq 0.05)$ between obtained values at different holding times for the prepared extract using $1.25 \%$ green tea. The radical scavenging activity of prepared green tea extracts at temperatures 80 and $100{ }^{\circ} \mathrm{C}$ was slightly negative affected compared to the obtained data of extracts prepared at $60^{\circ} \mathrm{C}$. According to the above results, it couldn't be accurately determined the optimum concentrations, temperatures or times to prepared the green tea extract with highest radical scavenging activity. The holding of antioxidants with $\mathrm{DPPH}^{\circ}$ radical would reduce the concentration of $\mathrm{DPPH}^{\circ}$ radical, lower the absorbance, and then provide a negative peak on a constant background signal, while for those without antioxidants effects would not change the constant background signal (Niederländer et al 2008). Selection of brewing temperature was based on the data on the loss of useful properties of green tea at higher temperatures (U Vey Sin, 2005). This is related to bioflavonoids' instability. The experiments affirmed literature references, indicating that green tea has antioxidant effect (Horzic et al 2009; Milašienè et al 2007).

\section{Polynomial cubic regression study}

\section{Green tea concentration versus DPPH' scav- enging activity}

The effect of green tea concentration on the radical scavenging activity was presented as a polynomial cubic trend in Fig. 1. The modeling expressed at $60^{\circ} \mathrm{C}$ and $30 \mathrm{~min}$. The green tea concentration had a significant $(P \leq 0.05)$ effect on the $\mathrm{DPPH}^{\circ}$ scavenging activity at holding time $30 \mathrm{~min}$ and temperature of extraction $60^{\circ} \mathrm{C}$. According to the polynomial cubic regression, (Eq. 7) the radical 
scavenging activity increased with increasing the green tea concentration from 0.25 to $1.0 \%$, followed by dramatic decreased by concentration more than $1.0 \%$ with correlation coefficient $\left(r^{2}=\right.$ $0.9861)$. Radical scavenging effects related to its affinity to the radical in the specific site. This finding is in according with those mentioned by (Sun, et al 2004). They stated that the radical scavenging ability has been decreased at high phenolic concentrations in the peroxyl radical system

$$
Y=15.8+187.6 X-158.8 X^{2}+43.3 X^{3}
$$

[Eq. 7]

The predicted radical scavenging activity increased from 53 to $88 \%$ with increasing the green tea concentration from 0.25 to $1.0 \%(\mathrm{w} / \mathrm{v})$, then decreased gradually to the minimum value (53\%) with increasing green tea concentration to $1.25 \%$ $(w / v)$. Catechins are the largest part of the polyphenols found in green tea and are effective free radical scavengers (Salah et al 1995).

\section{Extraction temperature versus $\mathrm{DPPH}^{\bullet}$ scaveng- ing activity}

Effect of different temperatures were used to preparation of green tea extracts at the green tea concentration $0.75 \%$ and holding time $30 \mathrm{~min}$ on $\mathrm{DPPH}^{\circ}$ scavenging activity presented in Fig. 1. Polynomial cubic regression (Eq. 8) used to predict the optimal temperature for extraction.

$$
Y=-273.9+14.3 X-0.184 X^{2}+8.0 \times 10^{-4} X^{3} \text { [Eq. 8] }
$$

Output data indicated that the temperature of extraction was a very effective factor to produce an extract with high radical scavenging efficiency with correlation coefficient $\left(r^{2}=1.0000\right)$. The predicted radical scavenging activity gradually increased from 53 to $89 \%$ with increasing the temperature of extraction from 40 to $66.4{ }^{\circ} \mathrm{C}$. On the other hand, with increasing the temperature of extraction the radical scavenging activity decreased gradually to $83 \%$ at temperature $100^{\circ} \mathrm{C}$. Dube et al 2010 reported that the catechins are chemically unstable.

\section{Holding time versus $\mathrm{DPPH}^{\circ}$ scavenging activity}

Effect of holding time on radical scavenging activity at green tea concentration $0.75 \%$ and temperature of extraction $60{ }^{\circ} \mathrm{C}$ presented in Fig. 1. Increase the percentage of scavenging with low holding time reflects the efficiency of the green tea extract as a radical scavenger. Polynomial cubic regression (Eq. 9) appeared the correlation between the holding time and radical scavenging activity with $r^{2}=0.9446$.

\section{$Y=82.9+5.539 X-0.019 X^{2}+2.0 \times 10^{-4} X^{3} \quad$ [Eq. 9]}

With increasing the holding time, the radical scavenging activity was increased. At holding time $1 \mathrm{~min}$ the radical scavenging activity reached to the maximum value was $88 \%$. Generally, the optimal predictive concentration, temperature and holding time for preparation of green tea extracts with high potential radical scavenging activity values were $1.0 \%, 66.7^{\circ} \mathrm{C}$ and $30 \mathrm{~min}$, respectively.

Table 2. Radical scavenging activity (\%) of prepared green tea aqueous extract prepared using different concentrations and temperatures during

\begin{tabular}{|c|c|c|c|c|c|}
\hline \multirow{2}{*}{ Time (min) } & \multicolumn{5}{|c|}{ Concentration (g/100 ml water) } \\
\hline & 0.25 & 0.5 & 0.75 & 1.0 & 1.25 \\
\hline & \multicolumn{5}{|c|}{$40^{\circ} \mathrm{C}$} \\
\hline 0 & $40^{\mathrm{Cd}}$ & $42^{\mathrm{Bd}}$ & $52^{\mathrm{Cc}}$ & $76^{\mathrm{Cb}}$ & $83^{\mathrm{Ca}}$ \\
\hline 5 & $40^{\mathrm{Ce}}$ & $42^{\mathrm{Bd}}$ & $53^{\mathrm{BC}}$ & $77^{\mathrm{Cb}}$ & $84^{\mathrm{Ba}}$ \\
\hline 10 & $40^{\mathrm{CBe}}$ & $42^{\mathrm{Bd}}$ & $54^{\mathrm{ABC}}$ & $77^{\mathrm{Cb}}$ & $85^{\mathrm{Aa}}$ \\
\hline 15 & $40^{\mathrm{CBe}}$ & $44^{\mathrm{Ad}}$ & $54^{\mathrm{AC}}$ & $79^{\mathrm{Bb}}$ & $85^{\mathrm{Aa}}$ \\
\hline 20 & $42^{\mathrm{ABCe}}$ & $46^{\mathrm{Ad}}$ & $54^{\mathrm{AC}}$ & $84^{\mathrm{Ab}}$ & $85^{\mathrm{Aa}}$ \\
\hline 25 & $43^{A C}$ & $46^{\mathrm{Ac}}$ & $54^{\mathrm{ABb}}$ & $84^{\mathrm{Aa}}$ & $85^{\text {Aa }}$ \\
\hline \multirow[t]{2}{*}{30} & $42^{\mathrm{ABd}}$ & $46^{\mathrm{AC}}$ & $53^{\mathrm{Bb}}$ & $85^{\text {Aa }}$ & $85^{\mathrm{Aa}}$ \\
\hline & \multicolumn{5}{|c|}{$60^{\circ} \mathrm{C}$} \\
\hline 0 & $44^{\mathrm{CC}}$ & $60^{\mathrm{Db}}$ & $83^{\mathrm{Ca}}$ & $84^{\mathrm{Ba}}$ & $86^{\mathrm{Ca}}$ \\
\hline 5 & $51^{\mathrm{Bd}}$ & $70^{\mathrm{Cc}}$ & $86^{\mathrm{Ba}}$ & $83^{\mathrm{Cb}}$ & $86^{\mathrm{Ca}}$ \\
\hline 10 & $51^{\mathrm{Be}}$ & $71^{\mathrm{BCd}}$ & $86^{\mathrm{Bb}}$ & $83^{\mathrm{Cc}}$ & $87^{\mathrm{Ba}}$ \\
\hline 15 & $51^{\mathrm{Be}}$ & $73^{A B d}$ & $88^{\mathrm{Aa}}$ & $86^{A C}$ & $87^{\mathrm{Bb}}$ \\
\hline 20 & $52^{\mathrm{Bd}}$ & $73^{\mathrm{ABC}}$ & $88^{\mathrm{Aa}}$ & $86^{A b}$ & $88^{\mathrm{Aa}}$ \\
\hline 25 & $52^{\mathrm{Bd}}$ & $73^{A B C}$ & $88^{\mathrm{Aa}}$ & $86^{A b}$ & $87^{\mathrm{ABa}}$ \\
\hline \multirow[t]{2}{*}{30} & $54^{\mathrm{Ae}}$ & $74^{\mathrm{Ad}}$ & $88^{\mathrm{Aa}}$ & $86^{A C}$ & $87^{A D}$ \\
\hline & \multicolumn{5}{|c|}{$80^{\circ} \mathrm{C}$} \\
\hline 0 & $51^{\mathrm{DC}}$ & $65^{\mathrm{Db}}$ & $77^{\mathrm{Ca}}$ & $77^{\mathrm{Ca}}$ & $76^{\mathrm{Ea}}$ \\
\hline 5 & $57^{\mathrm{Cd}}$ & $74^{\mathrm{Cc}}$ & $80^{\mathrm{Ba}}$ & $77^{\mathrm{Cb}}$ & $77^{\mathrm{Ub}}$ \\
\hline 10 & $59^{\mathrm{Bd}}$ & $76^{\mathrm{BCC}}$ & $81^{\text {Ba }}$ & $77^{\mathrm{Cb}}$ & $77^{\mathrm{Ub}}$ \\
\hline 15 & $60^{\mathrm{ABd}}$ & $77^{\mathrm{ABC}}$ & $83^{\mathrm{Aa}}$ & $78^{\mathrm{Bb}}$ & $78^{\mathrm{Cb}}$ \\
\hline 20 & $61^{\mathrm{ABd}}$ & $77^{\mathrm{ABC}}$ & $83^{\mathrm{Aa}}$ & $78^{\mathrm{Bb}}$ & $78^{\mathrm{Cb}}$ \\
\hline 25 & $61^{A d}$ & $78^{\mathrm{ABC}}$ & $83^{\mathrm{Aa}}$ & $78^{\mathrm{Bc}}$ & $79^{\mathrm{Bb}}$ \\
\hline \multirow[t]{2}{*}{30} & $62^{\mathrm{Ae}}$ & $79^{\mathrm{Ad}}$ & $83^{A a}$ & $80^{A C}$ & $81^{A b}$ \\
\hline & \multicolumn{5}{|c|}{$100^{\circ} \mathrm{C}$} \\
\hline 0 & $39^{\mathrm{Dd}}$ & $57^{\mathrm{Dc}}$ & $75^{\mathrm{ED}}$ & $77^{\text {Aab }}$ & $80^{\mathrm{ABa}}$ \\
\hline 5 & $44^{\mathrm{Ce}}$ & $64^{\mathrm{Cd}}$ & $75^{\mathrm{tc}}$ & $77^{\mathrm{Ab}}$ & $80^{\text {АВа }}$ \\
\hline 10 & $46^{\mathrm{Bd}}$ & $66^{\mathrm{BC}}$ & $78^{\mathrm{Db}}$ & $77^{A b}$ & $80^{\mathrm{ABa}}$ \\
\hline 15 & $46^{\mathrm{Be}}$ & $67^{\mathrm{ABd}}$ & $82^{\mathrm{Ca}}$ & $77^{A C}$ & $80^{\mathrm{ABb}}$ \\
\hline 20 & $47^{\mathrm{Be}}$ & $67^{\mathrm{ABd}}$ & $85^{\mathrm{ba}}$ & $77^{\mathrm{AC}}$ & $80^{\mathrm{ABD}}$ \\
\hline 25 & $48^{\mathrm{Ae}}$ & $69^{\mathrm{Ad}}$ & $86^{\mathrm{ABa}}$ & $77^{\mathrm{Ac}}$ & $80^{\mathrm{ABb}}$ \\
\hline 30 & $48^{\mathrm{Ae}}$ & $69^{\mathrm{Ad}}$ & $86^{\mathrm{Aa}}$ & $77^{A C}$ & $81^{\mathrm{Ab}}$ \\
\hline
\end{tabular}
different holding times

Means in the same column with different capital letters are significantly different $(P \leq 0.05)$. 
Antioxidant and Antiradical Activity of Green Tea (Camellia sinensis) Aqueous Extract and Its Capability to Retardation of Rats Liver Cirrhosis

Means in the same row with different small letters are
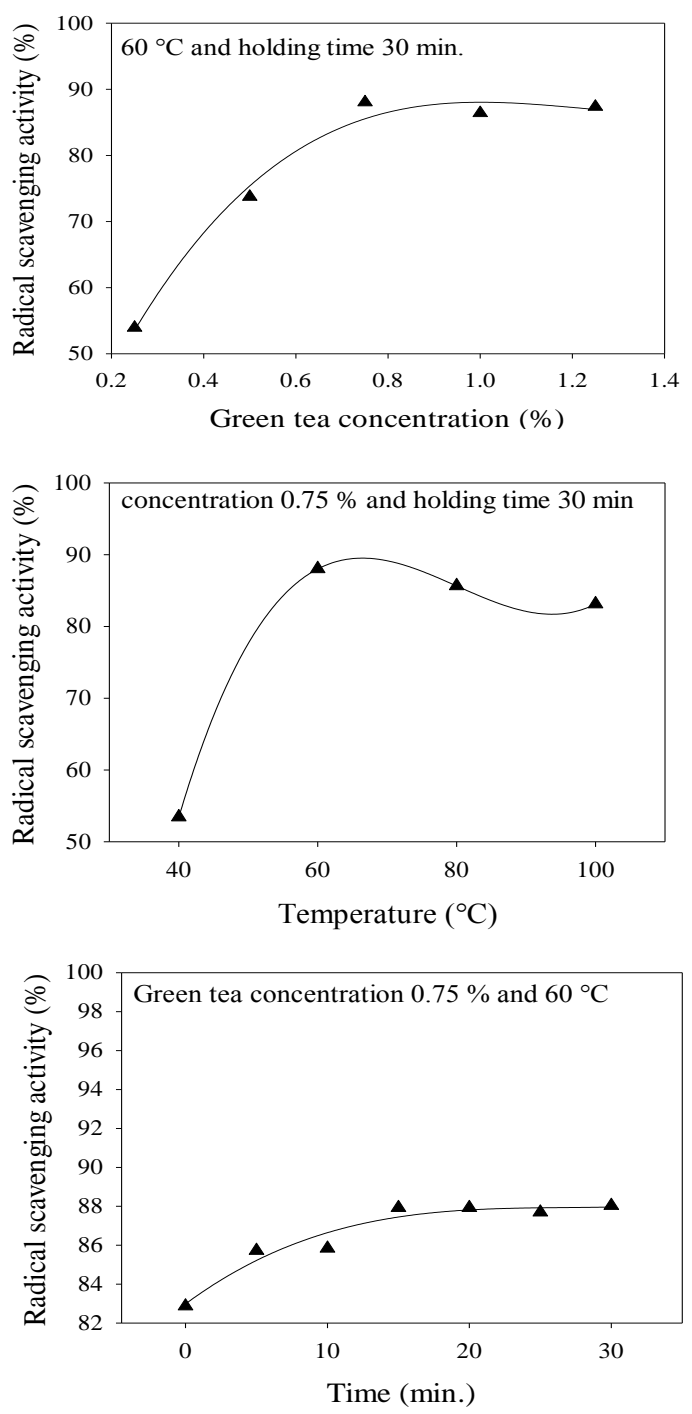

Fig. 1. Polynomial cubic trends of different green tea concentrations, preparation temperatures and holding times in prepared extracts versus radical scavenging activity

\section{Regression coefficient for each independent variable}

The concentration, temperature and holding time were tested as independent variable. Each one tested alone to predict the optimal value. Each model was tested for adequacy by analysis of variance. The regression models for data were significant $(P \leq 0.05)$ with $r^{2}$ ranged between 0.9446 to
1.000. The predicted model for radical scavenging activity $(\mathrm{Y})$ was reported as follows:

$$
y=y^{\circ}+a x+b x^{2}+c x^{3}
$$

Consequently, the obtained predicted models were possible for identify the optimum conditions required to produce a high potential effect of radical scavenging activity for prepared green tea extracts. It could be said that, the output predictive values not cleared the actual effect of the interaction between the three independent variables. The predictive radical scavenging activities 88.05, 89.52 and $87.95 \%$ at concentration $1.0 \%$, temperature $66.7^{\circ} \mathrm{C}$ and holding time $30 \mathrm{~min}$, respectively.

\section{Three dimension response surface study}

\section{Concentrations and temperatures versus DPPH ${ }^{\circ}$ scavenging activity}

The three dimension response surface plot in Fig. 2 is explaining the relationships between the radical scavenging activity and both green tea concentrations and temperature for prepared green tea extracts at temperatures of $40,60,80$ and $100{ }^{\circ} \mathrm{C}$. Scavenging activity increased by increasing both green tea concentration from 0.25 to $1.0 \%$ and temperature from 40 to $60^{\circ} \mathrm{C}$ at holding time $30 \mathrm{~min}$. In contrary, scavenging activity was decreased with increasing both concentration and temperature more than $1.0 \%$ and $60{ }^{\circ} \mathrm{C}$. Thermal treatment like pasteurization of tea extracts cause increased the antioxidant activity of extracts, which was attributed to the formation of compounds having antioxidant activity during heat treatment (Manzocco et al 1998). Response surface analysis showed significant $(P \leq 0.05)$ regression relationships between both of green tea concentration (G) and temperature $(T)$ as independent variables and radical scavenging activity (RSA) as response variable. The polyphenon 60 and guava leaf extracts showed weaker effects, at high concentrations, in antioxidant activity and peroxyl radical scavenging assays (Chen and Yen, 2007). The multiple hydroxyflavonoids, especially with $\mathrm{OH}$ in the $B$-ring, significantly increased production of hydroxyl radicals in a Fenton system (Hanasaki et al 1994). 


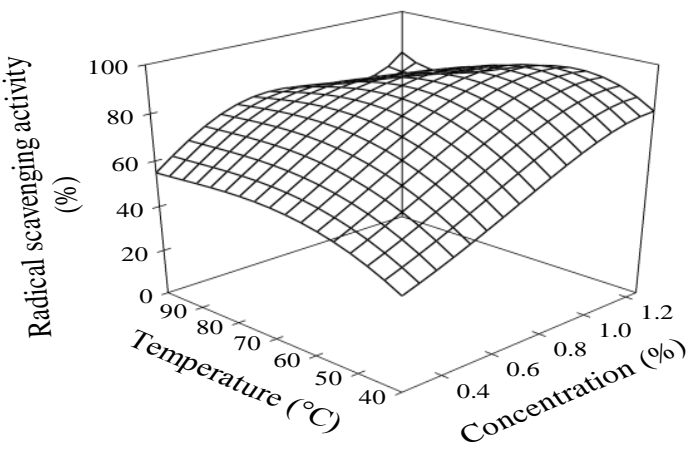

$R S A=-37.464+32.993 G+2.469 T-43.922 G^{2}-$ $0.017 T^{2}+66.030 G^{3}-8.316 T^{3}-30.922 G^{4}+$ $7.17 \times 10^{-7} T^{4}+0.029 G^{2} T^{2}-4.95 \times 10^{-4} G^{3} T^{3}+$ $0.0220 G^{4} T^{4}$

[Eq. 11]

On the other hand, prepared green tea extracts at $100{ }^{\circ} \mathrm{C}$ gave the lowest predicted radical scavenging with percent of $72.82 \%$ in the extract that prepared used green tea concentration of $1.06 \%$ and holding time $30 \mathrm{~min}$. The biomolecular matrices may be attacked by derivatives from sample components, especially the phenolic compounds, resulting in secondary oxidation damage (Chen and Yen 2007)

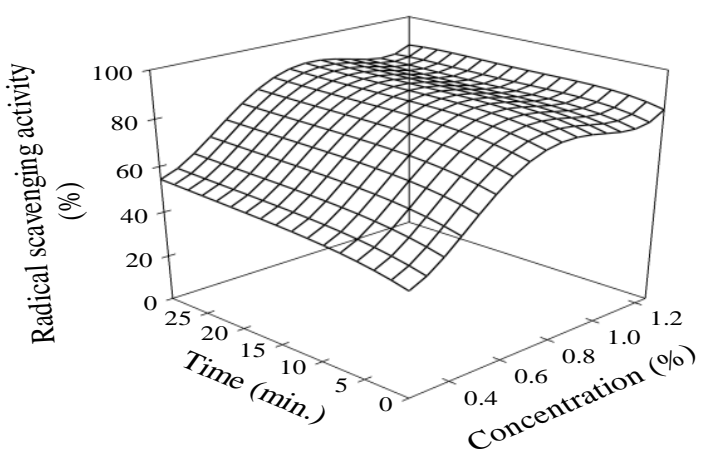

\section{Concentrations and times versus DPPH scav-} enging activity

Fig. 2 showed that the effect of different green tea concentrations ( $\mathrm{G}$ ) and holding times ( $\mathrm{t}$ ) on radical scavenging activity. Predicted model (Eq. 12) cleared that effect of holding time and concentration of green tea extract, which prepared at 60 ${ }^{\circ} \mathrm{C}$ on RSA as follows:

$R S A=70.155-296.832 G+1.019 t+1026.725 G^{2}-$ $0.050 t^{2}-1096.509 G^{3}+0.001 t^{3}+377.723 G^{4}-$

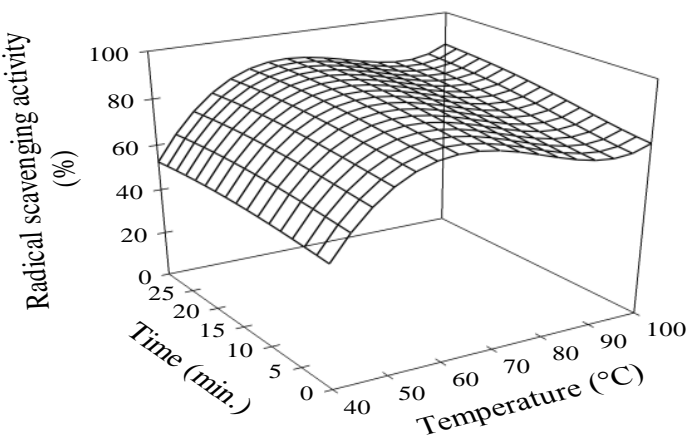
$1.39 \times 10^{-5} t^{4}-0.032 G^{2} t^{2}+0.001 G^{3} t^{3}-1.98 \times 10^{-5} G^{4} t^{4}$ [Eq. 12]

The highest scavenging value was $89.29 \%$ at green tea concentration $0.81 \%$ and holding time $30 \mathrm{~min}$ with $r^{2}=0.9900$. Jun et al 2011 revealed that the holding time had a significant effect on the $\mathrm{DPPH}^{\circ}$ inhibition rate. Increasing the holding time from 15 to $30 \mathrm{~min}$ lead to increase the inhibition rate. The higher the inhibition rate is, the greater the hydrogen donating ability, thus the higher antioxidant activities.

Fig. 2. Three dimension regression plot to predict the radical scavenging activity as dependent variable against different green tea concentrations, temperatures and holding times for preparation green tea extracts as independent variables.

The predicted model (Eq. 11) had a high correlation coefficient $\left(r^{2}=0.8700\right)$. From output data, it could be noticed that the best predicted radical scavenging activity for that equation was $93.04 \%$ at green tea concentration $1.06 \%$ and preparation temperature $62.5^{\circ} \mathrm{C}$.

\section{Temperatures and times versus DPPH' scav- enging activity}

Radical scavenging activity of different green tea extracts those prepared at different temperatures from 40 up to $100^{\circ} \mathrm{C}$ and holding time from 0 up to 30 min presented in Fig. 2. The best predicted scavenging efficiency was $89.36 \%$ for the prepared extract at $66.5^{\circ} \mathrm{C}$ and holding time was 26.3 min by used a constant concentration was $0.75 \%$. The Quaternary model (Eq. 13) appeared the best conditions from temperature $(\mathrm{T})$ and holding time (t) to obtained the highest radical scavenging activity with $r^{2}=0.9970$. 

Extract and Its Capability to Retardation of Rats Liver Cirrhosis

$R S A=-194.822+8.994 T+0.248 t-0.053 T^{2}-$ $0.011 t^{2}-6.52 \times 10^{-4} T^{3}-8.22 \times 10^{-5} t^{3}+5.56 \times 10^{-6} T^{4}+$ $1.42 \times 0^{-6} t^{4}+4.63 \times 10^{-5} T^{2} t^{2}-1.6 \times 10^{-9} T^{3} t^{3}+$ $2.15 \times 10^{-13} T^{4} t^{4}$ [Eq. 13]

Although the phenolics content in prepared ginger extract at $60^{\circ} \mathrm{C}$ were less than that prepared at room temperature, however it had a higher radical scavenging activity. Radical scavenging activity decreased with percent of $20 \%$ in the prepared tea extract at $100^{\circ} \mathrm{C}$ (Manzocco, et al 1998). Raw broccoli florets had total antioxidant activity measured by DPPH $^{*}$ with $60.5 \%$ but after cooking for 5 min by boiling the florets retained $35 \%$ of total antioxidant activity (Zhang and Hamauzu, 2004).

Predictive DPPH scavenging activity at each of two independent variables

Consequently, the obtained predicted models are possible for identify the optimum conditions (concentration, temperature and holding time) required to prepare a green tea extract with high potential efficiency of radical scavenging activity. It could be concluded that, the obtained models more accuracy to investigate the interaction effect between each two independent variables on the radical scavenging activity of the prepared green tea extracts. The highest predicted $\mathrm{DPPH}^{\circ}$ scavenging activity ranged between 89.29 to $93.04 \%$ at different predicted independent variables were concentration, temperature and time. Nevertheless, the interaction between the three independent factors not clear by using this surface study.

Regression coefficient for three (concentration, temperature and time) independent variables

Multiple regression coefficients were helped to predict quaternary model for radical scavenging activity. The table contain models to determine the interaction effect between those three independent variables on the radical scavenging activity of green tea extracts. The model interacted between the concentration $(C)$, temperature $(T)$ and time $(t)$. The model was tested for adequacy by analysis of variance. The regression model for data were significant $(P \leq 0.05)$ with correlation coefficient was 0.9115 . The predicted model for radical scavenging activity (RSA) was reported as follows:
$R S A=124.85-827.01006 C-0.36508 T+0.70106 t+$ $1086.9 C^{2}-0.02114 T^{2}-0.05420 t^{2}-730.624 C^{3}+$ $0.00010767 T^{3}+0.00225 t^{3}+187.56 C^{4}-0.0000325 t^{4}$ $+11.7509 C T-1.4767 C t+0.01633 T t-0.16155 C^{2} T^{2}$ $+0.10158 C^{2} t^{2}-0.0000125 T^{2} t^{2}+0.00107 C^{3} T^{3}-$ $0.00344 C^{3} t^{3}+4.770853 \times 10^{-9} T^{3} t^{3}-0.00000259 C^{4} T^{4}$ $+0.00004059 C^{4} t^{4}-6.6261 \times 10^{-13} T^{4} t^{4}$ [Eq. 14]

\section{Verification of predictive $\mathrm{DPPH}^{\circ}$ scavenging activity compared to BHT}

The verification of predicted green tea extract parameters to obtain the highest $\mathrm{DPPH}^{\circ}$ radical scavenging activity value compared to the responding of BHT at different concentrations presented in Table 3. The optimal predicted $\mathrm{DPPH}^{\circ}$ radical scavenging activity value was $81.3 \%$ with verified value $88.0 \%$. The predicted conditions of preparation were $1.0 \%$ green tea, $81.7^{\circ} \mathrm{C}$ and holding time $25 \mathrm{~min}$. The radical scavenging activity of BHT at concentrations 50, 100, 150 and 200 ppm were ranged between 83.9 to $86.8 \%$. It can be recommend using the green tea at concentration of $1.0 \%$ and preparation temperature $81.7^{\circ} \mathrm{C}$ to obtain the highest potential anti radical effect. The potential effect of extract that prepared using predicted conditions closed with the BHT effect at concentration $150 \mathrm{ppm}$.

Effect of concentrations and temperatures on the ferric reducing antioxidant power

Analysis of variance of ferric reducing antioxidant power (FRAP) for green tea extracts presented in Table 4. The extracts prepared at different concentrations ranged between 0.25 to $1.25 \%$ and temperatures ranged between 40 to $100^{\circ} \mathrm{C}$. It clearly noticed that the antioxidant power of different green tea extracts were greatly significantly $(P \leq 0.05)$ affected by the concentrations those used in preparation of extracts. It was gradually increased from 1.09 at concentration $0.25 \%$ to 2.54 at concentration $1.25 \%$ for the prepared extracts at $40^{\circ} \mathrm{C}$. The same trend was observed at all used temperatures. Increasing the green tea concentration the ferric reducing antioxidant power increased. 
Table 3. Optimal predictive preparation interaction conditions for green tea extracts to obtain the highest $\mathrm{DPPH}^{\circ}$ radical scavenging activity predictive value compared to verified values and respond of BHT at different concentrations

\begin{tabular}{|c|c|c|c|c|c|c|c|}
\hline \multirow[b]{2}{*}{$\begin{array}{c}\text { Independent } \\
\text { variables }\end{array}$} & \multirow{2}{*}{ 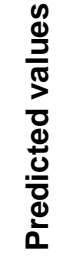 } & \multicolumn{2}{|c|}{ Dependent variable } & \multicolumn{4}{|c|}{ BHT (ppm) } \\
\hline & & 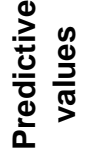 & 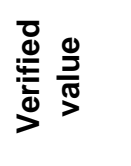 & 50 & 100 & 15 & 200 \\
\hline Concentration & 1.0 & & & & & & \\
\hline $\begin{array}{l}\text { Temperature } \\
\text { Holding time }\end{array}$ & $\begin{array}{r}88.7 \\
25\end{array}$ & 81.3 & 88.0 & 83.9 & 85.5 & 87.4 & 96.8 \\
\hline
\end{tabular}

Table 4. Ferric reducing antioxidant power (OD) of prepared green tea extract at different concentrations and temperatures

\begin{tabular}{|c|c|c|c|c|c|}
\hline \multirow{2}{*}{ Temperature $\left({ }^{\circ} \mathbf{C}\right)$} & \multicolumn{5}{|c|}{ Concentration (g/100 ml water) } \\
\cline { 2 - 6 } & $\mathbf{0 . 2 5}$ & $\mathbf{0 . 5}$ & $\mathbf{0 . 7 5}$ & $\mathbf{1 . 0}$ & $\mathbf{1 . 2 5}$ \\
\hline 40 & $1.09^{\mathrm{Dd}}$ & $1.99^{\mathrm{Cc}}$ & $2.55^{\mathrm{Ba}}$ & $2.522^{\mathrm{Cb}}$ & $2.54^{\mathrm{Ca}}$ \\
60 & $1.76^{\mathrm{Cd}}$ & $2.54^{\mathrm{Bb}}$ & $2.51^{\mathrm{Cc}}$ & $2.599^{\mathrm{Aa}}$ & $2.59^{\mathrm{Ba}}$ \\
80 & $1.91^{\mathrm{Bb}}$ & $2.55^{\mathrm{Ba}}$ & $2.56 \mathrm{~A}^{\mathrm{Ba}}$ & $2.556^{\mathrm{Ba}}$ & $2.54^{\mathrm{Ca}}$ \\
100 & $2.00^{\mathrm{Ae}}$ & $2.60^{\mathrm{Ab}}$ & $2.59^{\mathrm{Ac}}$ & $2.578^{\mathrm{ABd}}$ & $2.73^{\mathrm{Aa}}$ \\
\hline
\end{tabular}

Means in the same column with different capital letters are significantly different $(P \leq 0.05)$.

Means in the same row with different small letters are significantly different $(P \leq 0.05)$.

From the same Tables, the ferric reducing antioxidant power of green tea extracts also affected by the increasing of temperatures used in preparation. It markedly and progressively increased from 1.09 at temperature $40^{\circ} \mathrm{C}$ to 2.00 at temperature $100^{\circ} \mathrm{C}$ with significant difference $(P \leq 0.05)$ in extract that prepared using $0.25 \%$ green tea. In addition, the same tend was observed at all used concentrations. The higher the inhibition rate is, the greater the hydrogen donating ability, thus the higher antioxidant activities (Jun et al 2011).

\section{Polynomial cubic regression study for FRAP Concentration versus FRAP}

The effects of green tea concentration on FRAP was presented as a polynomial trend in Fig. 3. The green tea concentration had a significant $(P \leq 0.05)$ effect on the FRAP at constant temperature $\left(60^{\circ} \mathrm{C}\right)$. FRAP value increased from 1.75 to 2.59 with increasing the green tea concentration from 0.25 to $1.25 \%(\mathrm{~W} / \mathrm{V})$. According to the polynomial cubic regression, (Eq. 15) the FRAP increased with increasing the green tea concentration from 0.25 to $1.0 \%$, whereas constancy of values were observed at concentration more than 1.0 $\%$ with correlation coefficient was 0.9630 .

$$
Y=0.132+8.944 X-10.425 X^{2}+3.892 X^{3} \quad[E q .15]
$$

The predicted FRAP values increased from 1.77 to 2.61 with increasing the green tea concentration from 0.25 to $0.73 \%(\mathrm{w} / \mathrm{v})$, then decreased gradually to the minimum value was 2.06 with increasing green tea concentration to $1.25 \%(\mathrm{w} / \mathrm{v})$.

\section{Temperature versus FRAP}

Effects of different temperatures up to $100^{\circ} \mathrm{C}$ those used in preparation of green tea extracts on the potential FRAP was presented as a polynomial trend in Fig. 3. The polynomial regression was 


\section{Antioxidant and Antiradical Activity of Green Tea (Camellia sinensis) Aqueous Extract and Its Capability to Retardation of Rats Liver Cirrhosis}

expressed at constant concentration (0.75). The green tea extracts significantly $(P \leq 0.05)$ affected by different temperatures. FRAP values gradually increased from 2.55 to 2.59 with increasing the temperature with significant $(P \leq 0.05)$ differences. Upon the basis of apparent changes in efficiency of extraction affected by temperature as well as taking into account the cost of energy. The predicted temperature $95.78{ }^{\circ} \mathrm{C}$ was chosen for the optimization of extraction. The highest predicted FRAP value was 2.59 observed at the previous predicted temperature. The polynomial model that used in prediction process as follows:

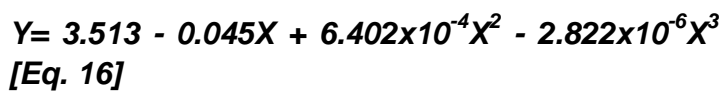

Regression coefficient for each independent variable for FRAP

Multiple regression coefficients of predicted cubic polynomial models for the dependent variable (FRAP) were estimated. The green tea concentration was the independent variable ranged between 0.25 to $1.25 \%$ by used the constancy temperature $\left(60^{\circ} \mathrm{C}\right)$ in preparation of the extracts. In addition, the temperature was also an independent variable ranged between 40 to $100^{\circ} \mathrm{C}$ by used the constancy green tea concentration $(0.75 \%)$. The green tea concentration and preparation temperature had a significant $(P \leq 0.05)$ effect on the obtained FRAP values. Equation 17 was used to predict the FRAP at different concentrations. Lowest and highest predicted FRAP values were 1.77 and 2.61 at green tea concentrations 0.25 and $0.71 \%$.

$Y=0.132+8.944 X-10.425 X^{2}+3.892 X^{3}$ [Eq. 17]

According to equation (18) the FRAP gradually increased from 2.55 at $40^{\circ} \mathrm{C}$ of extraction to the maximum level was 2.59 at $95.78^{\circ} \mathrm{C}$ at constancy concentration was $0.75 \%$.

\section{$Y=3.513-0.045 X+6.402 \times 10^{-4} X^{2}-2.822 \times 10^{-6} X^{3}$ [Eq. 18]}

The models were tested for adequacy by analysis of variance. The regression models for data were significant $(P \leq 0.05)$ with $r^{2}$ were 0.9630 and 1.000. According to the models it is cleared that, the potential FRAP was affected by both of green tea concentration and temperature of preparation.
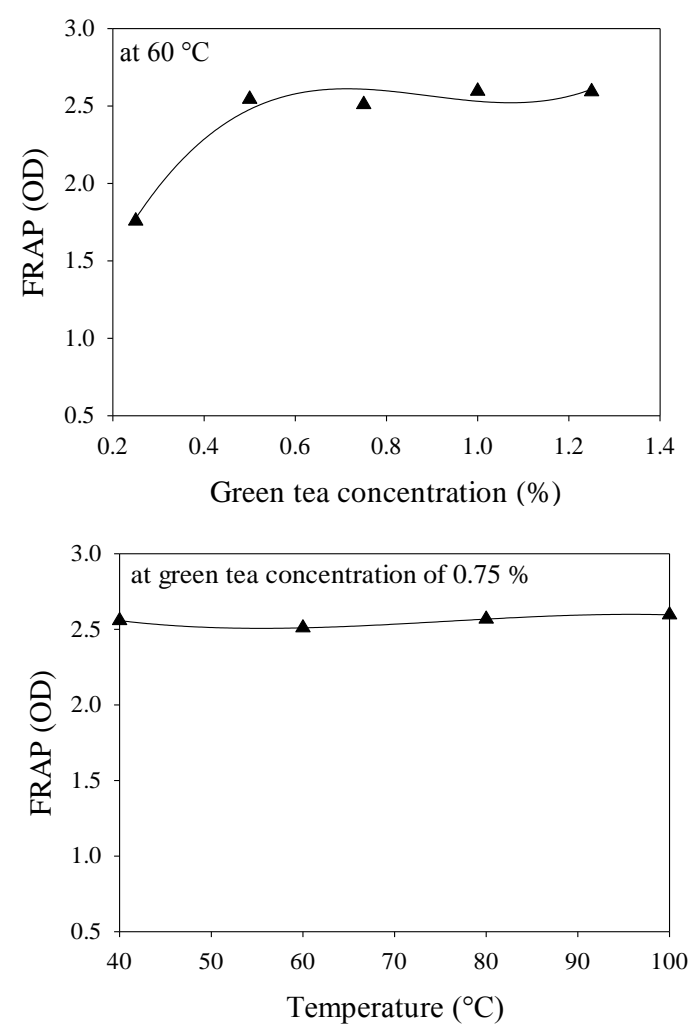

Fig. 3. Polynomial cubic trends of different green tea concentrations and temperatures of preparation in prepared extracts versus ferric reducing antioxidant power

In the predicted of two independent variables, both of concentration and temperature of green tea extraction preparation with high FRAP value was established. The highest FRAP values were 2.6118 and 2.5995 selected at predicted green tea concentration and preparation of temperature 0.71 $\%$ and $95.78{ }^{\circ} \mathrm{C}$, respectively. Although, the previous models cleared the effects each of green tea concentration and preparation of temperature on the extracts antioxidant power, but not investigated the effect of interaction between the two variables.

\section{Three dimension response surface study FRAP}

The previous polynomial cubic regression for each independent variables were green tea concentrations (G) and temperature ( $T$ ) appeared slight effect of temperature and high effect of concentrations on the FRAP values as dependent variable. Therefore, the three dimension response surface study was necessary to optimize the com- 
bined concentrations from green tea and temperature of preparation. The plot in Fig. 4 shows the response surface of FRAP as observed with changing of green tea concentrations and temperature of preparation. The predicted model (Eq. 19) had a high correlation coefficient $\left(r^{2}=0.9780\right)$. From output data, it could be noticed that the best predicted FRAP value for that equation was 2.566 at predicted concentration and temperature were $1.0 \%$ and $88.7{ }^{\circ} \mathrm{C}$. The FRAP values of $\mathrm{BHT}$ at concentrations 50, 100, 150 and 200 ppm were $1.627,1.720,2.390$ and 3.060 , respectively. The green tea extract that prepared at $1.0 \%$ had FRAP equivalent closed with BHT solution at concentration 200 ppm.

$F R A P=-3.508+0.074 G+12.189 T-2.290 \times 10^{-4} G^{2}$ $-13.418 T^{2}-4.524 \times 10^{-6} G^{3}+6.983 T^{3}+3.113 \times 10^{-8} G 4$ $-1.246 T^{4}-9.478 \times 10^{-4} G^{2} T^{2}+1.150 \times 10^{-5} G^{3} T^{3}$. $4.087 \times 10^{-8} \mathrm{G}^{4} T^{4}$

[Eq. 19]

The improved antioxidant activities of green tea extract can be exploited as dietary supplement in foods and beverages or in nutraceutical applications (Ong and Annuar, 2017).

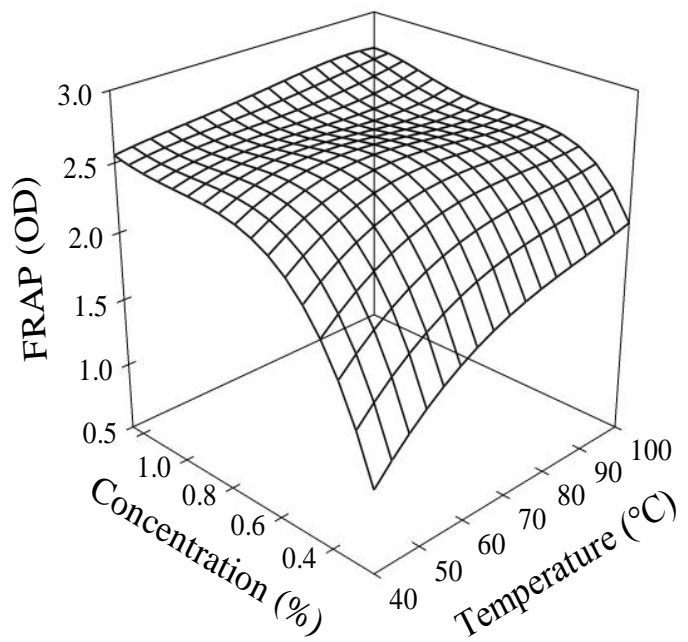

Fig. 4. Three dimension regression plot to predict the ferric reducing antioxidant power as dependent variable against different concentrations and temperatures for preparation of green tea extracts as independent variables

\section{Effect of concentrations and temperatures on the reducing power}

The effect of green tea extracts prepared using different concentrations and temperatures on the reducing power (RP) was presents in Table 5. The green tea concentration was ranged between 0.25 to $1.25 \%$. The green tea concentration had a significant $(P \leq 0.05)$ effect on the RP values. RP significant increased from 1.06 to 1.62 with increasing the green tea concentration from 0.25 to $1.25 \%$ at preparation temperature $40^{\circ} \mathrm{C}$. The same trend was observed with the extracts those prepared at $100^{\circ} \mathrm{C}$. The RP increased from 1.37 to 2.00 at concentrations 0.25 and $1.25 \%$ with significant differences. Non-significant $(P \geq 0.05)$ differences between obtained RP values for the extracts prepared from 1.0 or $1.25 \%$ green tea at al used temperature of preparation.

On the other hand, the obtained data proved that the preparation temperature significant $(P \leq 0.05)$ effect in the extracts RP. The RP value gradually increased with increasing the temperature from 40 to $100{ }^{\circ} \mathrm{C}$ reached up to 1.37. Also, the RP reached to the maximum value with the extract that prepared using $1.25 \%$ green tea and prepared at $100{ }^{\circ} \mathrm{C}$. Generally, each of green tea concentration and preparation temperature effects in the RP of prepared extract. It cannot determine the optimal conditions to prepare the green tea extract with high potential RP.

Table 5. Reducing power (OD) of prepared green tea extracts at different concentrations and temperatures

\begin{tabular}{|c|c|c|c|c|c|}
\hline \multirow{2}{*}{$\begin{array}{c}\text { Temperature } \\
\left({ }^{\circ} \mathbf{C}\right)\end{array}$} & \multicolumn{4}{|c|}{ Concentration (g/100 ml water) } \\
\cline { 2 - 6 } & $\mathbf{0 . 2 5}$ & $\mathbf{0 . 5}$ & $\mathbf{0 . 7 5}$ & $\mathbf{1 . 0}$ & $\mathbf{1 . 2 5}$ \\
\hline 40 & $1.06^{\mathrm{Bb}}$ & $1.42^{\mathrm{Bab}}$ & $1.48^{\mathrm{Bab}}$ & $1.54^{\mathrm{Ca}}$ & $1.62^{\mathrm{Ca}}$ \\
60 & $1.16^{\mathrm{Bb}}$ & $1.53^{\mathrm{ABab}}$ & $1.52^{\mathrm{ABab}}$ & $1.60^{\mathrm{BCab}}$ & $1.66^{\mathrm{Ca}}$ \\
80 & $1.45^{\mathrm{Aa}}$ & $1.47^{\mathrm{ABa}}$ & $1.47^{\mathrm{Ba}}$ & $1.68^{\mathrm{ABa}}$ & $1.83^{\mathrm{Ba}}$ \\
100 & $1.37^{\mathrm{Ac}}$ & $1.59^{\mathrm{Abc}}$ & $1.59^{\mathrm{Abc}}$ & $1.71^{\mathrm{Aab}}$ & $2.00^{\mathrm{Aa}}$ \\
\hline
\end{tabular}

Means in the same column with different capital letters are significantly different $(P \leq 0.05)$.

Means in the same row with different small letters are significantly different $(P \leq 0.05)$. 
Antioxidant and Antiradical Activity of Green Tea (Camellia sinensis) Aqueous Extract and Its Capability to Retardation of Rats Liver Cirrhosis

\section{Polynomial cubic regression study of reducing power}

\section{Concentration versus reducing power}

The effects of green tea extracts prepared at $60{ }^{\circ} \mathrm{C}$ on RP at different concentrations was presented as a polynomial trend in Fig. 5. Increased the green tea concentration lead to enhance the $\mathrm{RP}$ of extracts. However, the maximum RP was increased with increasing the green tea concentration to 1.66 with value was $1.25 \%$. According to the obtained results nonlinear relation between the green tea concentration and RP. According to the polynomial trend that obtained from equation 20 the maximum RP was 1.67 at $1.25 \%$ green tea. The equation had a significant effect with correlation coefficients was 0.9710 .

\section{$Y=0.387+4.280 X-5.069 X^{2}+1.995 X^{3}$ [Eq. 20]}

Consequently, the obtained predicted model appeared the enhancement in the green tea extracts behavior with the different concentrations. However, it could not use the green tea concentration alone to prepare suitable tea extract with high potential RP.
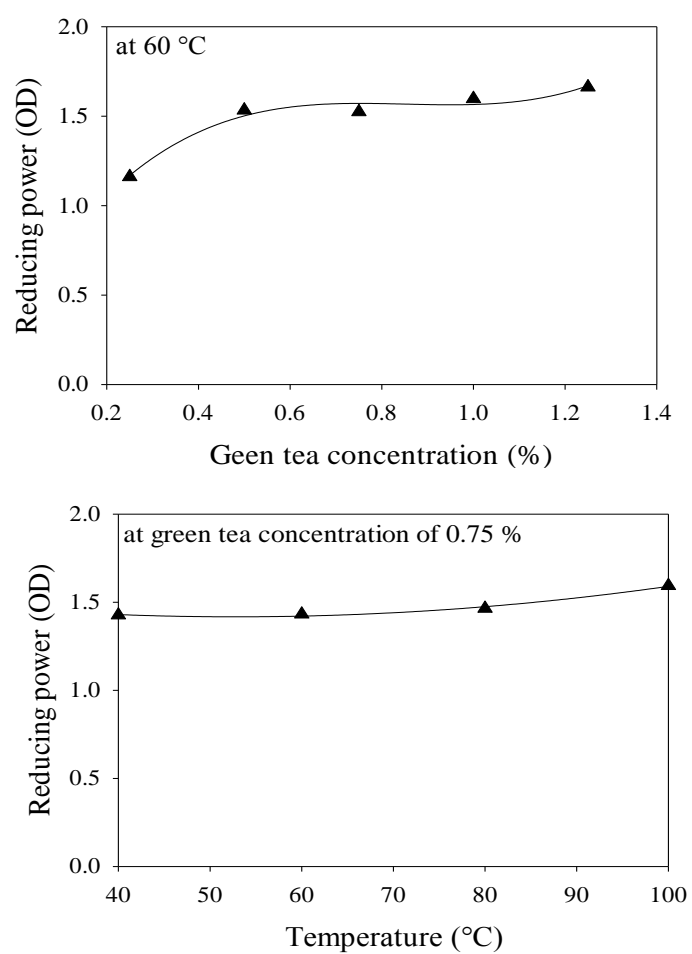

Fig. 5. Polynomial cubic trends of different green tea concentrations and temperatures of preparation in prepared extracts. versus reducing power

\section{Temperature versus reducing power}

Effects of different temperatures ranged from 40 to $100^{\circ} \mathrm{C}$ used in preparation of green tea extracts at concentration 0.75 on the RP was presented as a polynomial trend in Fig. 5. The temperature had a slight effect on the antioxidant power of the prepared green tea extracts compared to that effect of concentration. The green tea extracts significantly $(P \leq 0.05)$ affected by different temperatures. Reducing power values gradually increased from 1.42 to 1.59 with increasing the temperature with significant differences. Upon the basis of apparent changes in efficiency of extraction slightly affected by temperature the equation 21 can be fit the obtained data. The predicted temperature $100{ }^{\circ} \mathrm{C}$ was chosen for the optimization of extraction. The highest predicted RP value was 1.59, which observed at the previous predicted temperature. The polynomial model that used in prediction process was as follows:

$$
Y=1.634-0.008 X+7.750 \times 10^{-5} X^{2}
$$

[Eq. 21]

The quadratic equation had a significant effect with correlation coefficients was 0.9870 .

\section{Regression coefficient for each independent variable for reducing power}

Multiple regression coefficients of predicted cubic and quadratic polynomial models for RP as dependent variable were estimated. The used green tea concentrations were ranged between 0.25 to $1.25 \%$ as independent variable. The extracts prepared by used the constancy moderate temperature was $60^{\circ} \mathrm{C}$. In addition, the temperature was also an independent variable ranged between 40 to $100^{\circ} \mathrm{C}$ by used the constancy green tea concentration $(0.75 \%)$. The green tea concentration and preparation temperature had a significant effect on the obtained RP values. Equation 22 was used to predict the RP at different concentrations. Lowest and highest predicted RP values were 1.16 and 1.67 at green tea concentrations 0.25 and $1.25 \%$.

$$
Y=0.387+4.280 X-5.069 X^{2}+1.995 X^{3} \text { [Eq. 22] }
$$

According to equation 23 the RP gradually increased from 1.42 at $40^{\circ} \mathrm{C}$ of extraction to the maximum level was 1.59 at $100^{\circ} \mathrm{C}$ at constancy concentration was $0.75 \%$. 


$$
Y=1.634-0.008 X+7.750 \times 10^{-5} X^{2}
$$

[Eq. 23]

The models were tested for adequacy by analysis of variance. The regression models for data were significant with $r^{2}$ were 0.9710 and 0.9870 . According to the models it is cleared that, the potential RP was affected by both of green tea concentration and temperature of preparation.

The predicted of two independent variables, both of concentration and temperature of green tea extraction preparation with high RP value concluded. The highest RP values were 1.6706 and 1.5960 selected at predicted green tea concentration and preparation of temperature $1.25 \%$ and $100{ }^{\circ} \mathrm{C}$, respectively. The models cleared the separately effects each of green tea concentration and preparation temperature on the power of extracts reducing, but not fit the effect of interaction between the two variables.

\section{Three dimension response surface study of reducing power}

Three-dimension response surface method was used to study the relationship between concentration and preparation temperature of extract on RP efficiency for green tea water extracts. According to Figure 6 the RP was increased with increasing both of green tea concentration and preparation temperature (up to $89^{\circ} \mathrm{C}$ ). In contrary, at high temperature the RP was decreased. Output data of response surface study showed significant $(P \leq 0.05)$ relationships between both of green tea concentration and temperature of extraction as independent variables and RP as dependent variable. The predictive equation (Eq. 24) shows the effect of green tea concentration (G) and temperature of extraction ( $T$ ) on reducing power (RP). The predicted model (Eq. 24) had a high correlation coefficient $\left(r^{2}=0.9550\right)$. According to output data, it could be said that the best predicted RP value for that equation was 1.687 at predicted concentration and temperature were $1.0 \%$ and $88.7^{\circ} \mathrm{C}$. The RP values of $\mathrm{BHT}$ at concentrations $50,100,150$ and 200 ppm were 0.306, 0.878, 1.417 and 2.012, respectively. The green tea extract that prepared at $1.0 \%$ had RP equivalent closed with BHT solution at concentration $200 \mathrm{ppm}$.

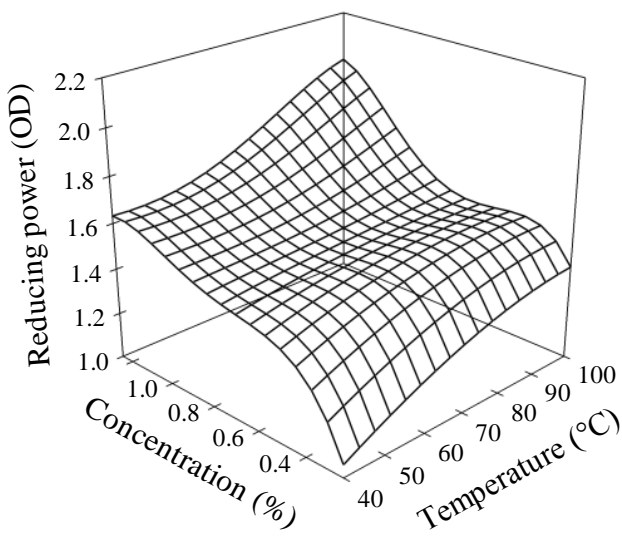

Fig. 6. Three dimension regression plot to predict the reducing power as dependent variable against different concentrations and temperatures for preparation of green tea extracts as independent variables

$R P=-0.695+0.011 G+8.220 T+3.183 \times 10^{-5} G^{2}-$ $14.671 T^{2}-5.793 \times 10^{-7} G^{3}-12.269 T^{3}+8.729 \times 10^{-}$ ${ }^{10} G^{4}-3.687 T^{4}-3.825 \times 10^{-4} G^{2} T^{2}+4.932 \times 10^{-6} G^{3} T^{3}-$ $1.720 \times 10^{-8} G^{4} T^{4}$

[Eq. 24]

Jeu-Ming et al 2015 revealed that the green tea extract using cold water had a high potential antioxidant activity compared to the extract prepared by hot water. Evstigneeva et al (2016) found out the preferred brewing dry green tea leaves in water was $70{ }^{\circ} \mathrm{C}$ followed by exposure for $10 \mathrm{~min}$ with continuous agitation.

\section{Total Phenolic and flavonoid contents}

Total phenolics and flavonoids content in green tea extracted using optimal conditions presented in Fig. 7. These extract was prepared at green tea concentration $1 \%$ in water at $88.7^{\circ} \mathrm{C}$. According to the previous data, those conditions gave extractable phenolics and flavonoids with high potential effects. The total phenolics in green tea extract was $81.2 \mathrm{mg} \mathrm{GAE} / 100 \mathrm{ml}$, that mean each gram from dry tea leaves contained $81.2 \mathrm{mg} \mathrm{GAE} / \mathrm{g}$. In addition, the total flavonoids in green tea extract was $33.5 \mathrm{mg} \mathrm{QE} / 100 \mathrm{ml}$ with equivalent weight 

Extract and Its Capability to Retardation of Rats Liver Cirrhosis

$33.5 \mathrm{mg} \mathrm{QE} / \mathrm{g}$ dry tea leaves. The obtained results closed with those findings by Nor Qhairul Izzreen and Mohd Fadzelly, (2013) indicated that the each gram from dry green tea contained total phenolics ranged between 63.87 to $80.27 \mathrm{mg} \mathrm{GAE}$. At the same time, the total flavonoids ranged between 20.90 to $35.17 \mathrm{mg} \mathrm{QE} / \mathrm{g}$.

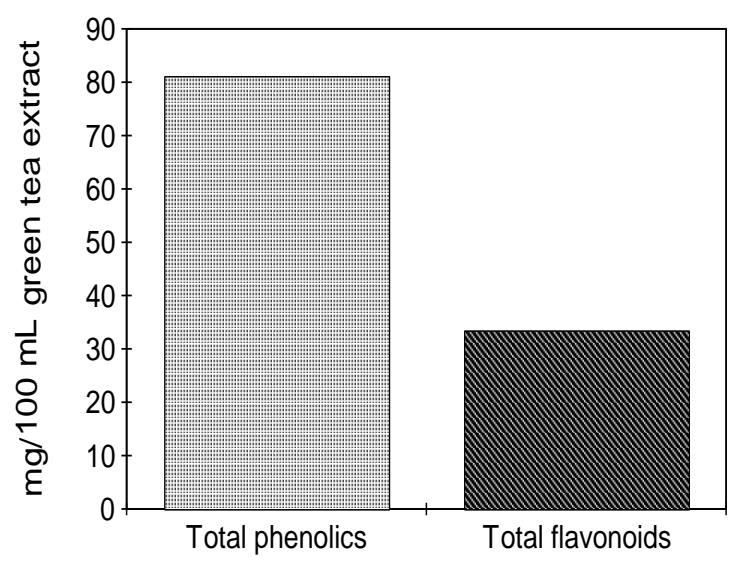

Fig. 7. Total phenolics (mg GAE/100 ml) and total flavonoids (mg QE/100 ml) in green tea water extracts at optimal extraction conditions

\section{Hepatic biomarkers}

The effect of $\mathrm{CCL}_{4}$ administration and the modulatory activities of green tea extract on the hematological parameters of rats shown in Fig. 8. A significant $(P \leq 0.05)$ decrease in serum total protein and albumin observed in cirrhosis group (G2) that treated by $\mathrm{CCl} 4$. The serum proteins dramatically decreased to the minimum levels of 5.31 and $2.91 \mathrm{~g} / \mathrm{dl}$, respectively. However, administration of aqueous extract of green tea corrected the trend of total protein and albumin in G3 compared to the obtained trend in G2. Non-significant $(P \geq 0.05)$ difference was observed between the values those obtained from each groups (G1 and G3). As in the current study, previous experimental studies have shown that $\mathrm{CC}_{4}$ decreased total protein and albumin levels (Fahim et al 1999; Khan and Alzohairy, 2011; Althnaian et al 2013). The activities of ALT and AST were estimated in serum as hepatic biomarkers of liver function. The $\mathrm{CCl}_{4}$ treatment markedly affected in the liver specific enzymes. Significant $(P \leq 0.05)$ increase in the serum ALT and AST activities were observed in the cirrhotic group (G2). The ALT and AST increased dramatically from 44 and $182 \mathrm{u} / \mathrm{l}$ at zero time to 73 and $221 \mathrm{u} / \mathrm{l}$ after twelve weeks, respectively. The rats induced by $\mathrm{CCL}_{4}$ had been increase in serum ALT and AST levels that source from cell membrane and mitochondrial damages in liver cell (Zimmerman et al 1965; El-Bahr, 2014; AlSultan and El-Bahr, 2015). Non-significant $(P \geq 0.05)$ effect observed in the negative group (G1) in the ALT and AST activities that arrived to the maximum level was 46 and $165 \mathrm{u} / \mathrm{l}$, respectively. The group (G3) treated by green tea extract appeared trend closed with that obtained with $\mathrm{G} 1$. The ALT and AST activities protective factors in G3 compared to those in G2 were 1.91 and 5.68, respectively. According to previous observations, the green tea extract prepared at optimal conditions and had high antiradical and antioxidant activities played roll in retardation of the liver cirrhosis with non-significant differences compared to G1. Similar results have been reported by Albokhadaim, (2016). The increased serum levels of hepatic transaminases biomarkers have been attributed to the liver injury, because these enzymes are place in cytoplasmic area of the cell and are released into circulation in case of cellular damage (Brent and Rumack, 1993; Recknagel et al 1989)

\section{Histopathological findings}

Sections in livers for rats in negative group (G1), cirrhotic positive group (G2) and treated group by green tea extract (G3) shown in Fig. 9. There was no histopathological alteration and the normal histological structure of the central vein and surrounding hepatocytes in the parenchyma were recorded in G1 A. Thickening with collagen proliferation as well as inflammatory cells infiltration and degeneration in the underlying hepatocytes in the parenchyma were recorded in G2 B1. Fatty change was observed in diffuse manner all over the hepatocytes in the parenchyma (G2 B2). The portal area showed inflammatory cells infiltration and few fibroblastic cells proliferation (G2 B3). Focal steatosis was detected in between the hepatic lobules (G2 B4). Focal steatosis was detected in the glissons capsule (G3 $\mathrm{C} 1$ ), while the hepatocytes in the parenchyma were intact (G3 C2). 

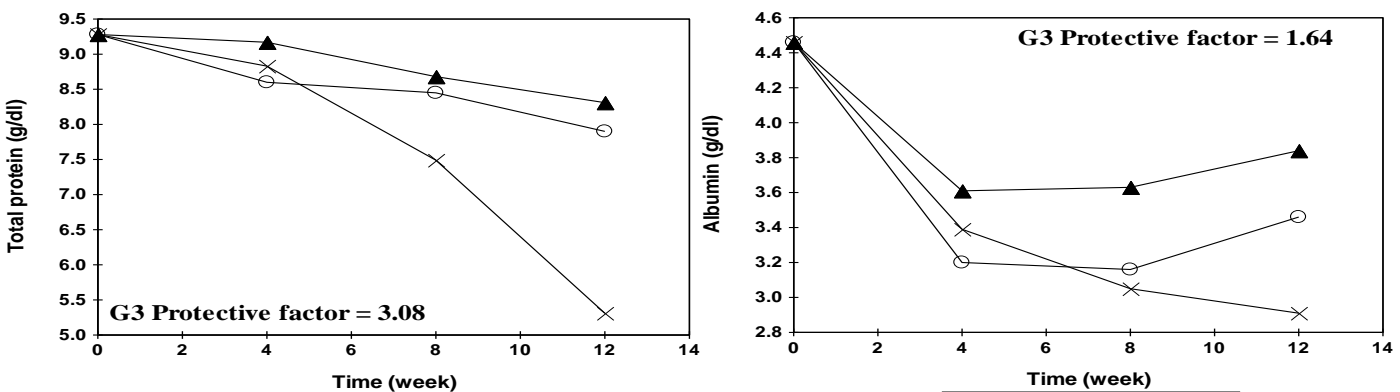

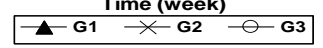
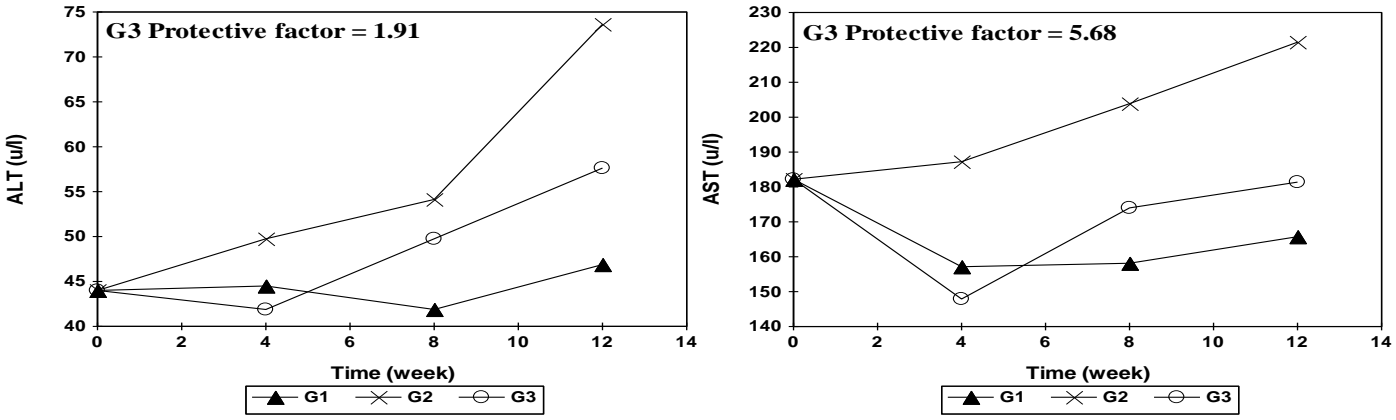

Fig. 8. Effect of green tea extract prepared at optimal conditions on the total protein, albumin, ALT and AST in rates had chronic liver cirrhosis for twelve weeks
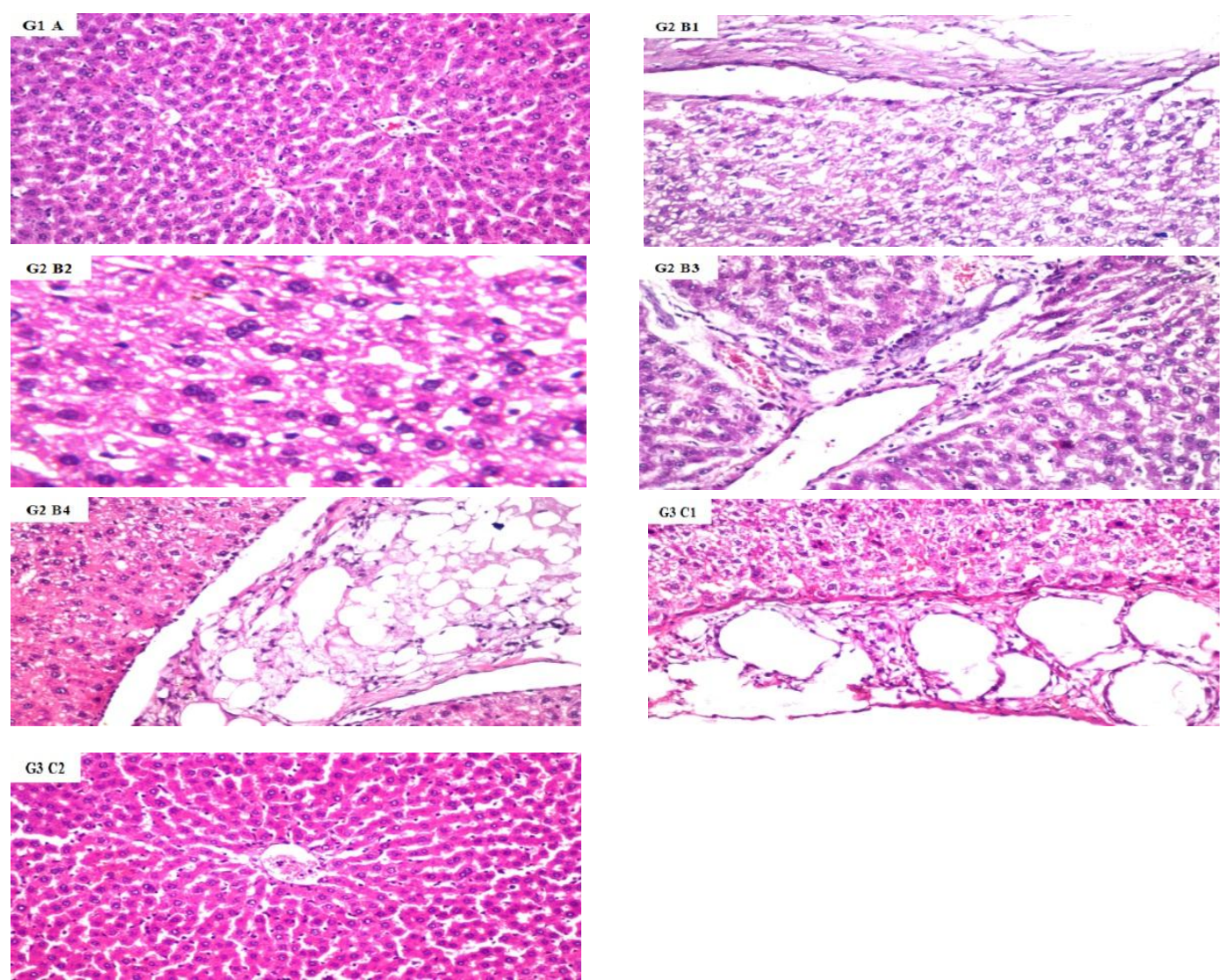

Fig. 9. Sections in livers for rats in negative group (G1), cirrhotic positive group (G2) and treated group by green tea extract (G3) 

Extract and Its Capability to Retardation of Rats Liver Cirrhosis

\section{CONCLUSION}

According to the obtained results, using of $1.0 \%$ green tea and water at $88.7^{\circ} \mathrm{C}$ was the most efficient set of conditions for the preparation of green tea extract with a potential antiradical and antioxidant effects closed with BHT solution effects. Prepared green tea extract using concentration higher than $1.0 \%$ had a non-significant $(P \geq 0.05)$ potential effects. In addition, using water with temperature higher than $88.7^{\circ} \mathrm{C}$ gave an extract with destroyed phenolics had a low radical scavenging and antioxidant activity. Utilization of green tea that prepared at previous predicted conditions could be suggested to protect rats livers against cirrhosis according to the obtained serum biomarkers and histological finings.

\section{REFERENCES}

Albokhadaim I. 2016. Effect of Aqueous Extract of Green Tea (Camellia sinensis) on Hematology and Oxidative Stress Biomarkers in Rats Intoxicated with Carbon Tetrachloride. J. of Biological Sci., 16, 49-57.

Al-sultan S.I. and El-Bahr S.M. 2015. Effect of aqueous extract of fenugreek (Trigonella foenum-graecum L.) on selected biochemical and oxidative stress biomarkers in rats intoxicated with carbon tetrachloride. International $\mathbf{J}$. Pharmacology 11, 43-49.

Althnaian T., Albokhadaim I. and El-Bahr S.M. 2013. Biochemical and histopathological study in rats intoxicated with carbon tetrachloride and treated with camel milk. Springerplus. 57, 2-7.

Banchroft J.D., Stevens A. and Turner D.R. 1996. Theory and practice of histological techniques. ( $4^{\text {th }}$ ed.). 766 p. Churchil Livingstone, New York, USA.

Baptista J.A.B., Tavares J.F.D. and Carvalho R.C.B. 1998. Comparison of catechins and aromas among different green teas using HPLC/SPME-GC. Food Research International 31, 729-736.

Benzie, I.F.F. and Strain, J.J. 1996. The Ferric Reducing Ability of Plasma (FRAP) as a Measure of "Antioxidant Power": The FRAP Assay. Analytical Biochemistry J. 239, 70-76.

Birkenfeld A.L. and Shulman G.I. 2014. Nonalcoholic fatty liver disease, hepatic insulin resistance, and type 2 diabetes. Hepatology 59, 713-723.

Brand-Williams W., Cuvelier M.E. and Berset C. 1995. Use of a free radical method to evaluate antioxidant activity. LWT-Food Sci. and Technology 28, 25-30.
Brent J.A. and Rumack B.H. 1993. Role of free radicals in toxic hepatic injury II. Are free radicals the cause of toxin-induced liver injury. J. of Clinical Toxicology 31, 173-196.

Budryn G., Zyz-elewicz D., Nebesny E., Oracz J. and Krysiak W. 2013. Influence of addition of green tea and green coffee extracts on the properties of fine yeast pastry fried products. Food Research International 50, 149-160.

Chan E.S., Yim Z.H., Phan S.H., Mansa R.F. and Ravindra P. 2010. Encapsulation of herbal aqueous extract through absorption with caalginate hydrogel beads. Food and Bioproducts Processing 88, 3195-3201.

Chan E.W.C., Soh E.Y., Tie P.P. and Law Y.P. 2011. Antioxidant and antibacterial properties of green, black, and herbal teas of (amellia sinensis). Pharmacognosy Research 3, 266272.

Chen H. and Yen G. 2007. Antioxidant activity and free radical-scavenging capacity of extracts from guava (Psidium guajava L.) leaves. Food Chemistry 101, 686-694.

Clarke K.A., Dew T.P., Watson R.E., Farrar M.D., Osman J.E. and Nicolaou A. 2016. Green tea catechins and their metabolites in human skin before and after exposure to ultraviolet radiation. The J. of Nutrition Biochemistry 27, 203-210.

Dube A., Ken N., Nicolazzo J. and Larson I. 2010. Effective use of reducing agents and nanoparticle encapsulation in stabilizing catechins in alkaline solution. Food Chemistry 122, 662667.

Duncan D.B. 1955. Multiple range and multiple $F$ tests. Biometrics 11, 1-42.

Eberhardt M.V., Lee C.Y. and Liu R.H. 2000. Nutrition-antioxidant activity of fresh apples. Nature 405, 903-904.

Ehrinpreis M.N., Giambrone M.A. and Rojkind M. 1980. Liver proline oxidase activity and collagen synthesis in rats with cirrhosis induced by carbon tetrachloride. Biochemistry Biophysics Acta 629, 184-193.

El-Bahr S.M. 2014. Camel milk regulates gene expression and activities of hepatic antioxidant enzymes in rats intoxicated with carbon tetrachloride. Asian J. of Biochemistry 9, 30-40.

Evstigneeva T., Skvortsova N. and Yakovleva R. 2016. The application of green tea Extract as a source of antioxidants in the processing of dairy products. Agronomy Research 14, 1284-1298.

Fahim F.A., Esmat A.Y., Fadel H.M. and K.F. 1999. Allied studies on the effect of (Rosmarinus officinalis L.) on experimental Hassan 
hepatotoxicity and mutagenesis. International J. of Food Science and Nutrition 50, 413427.

Gaur S. and Agnihotri R. 2014. Green tea: a novel functional food for the oral health of older adults. Geriatrics and Gerontology International 14, 238-250.

Gramza1 K., Pawlak-Lemañska, Korczak1, J., E., Sowicz W. and Rudzinska M. 2005. Tea Extracts as Free Radical Scavengers. Polish J. of Environmental Studies 14, 861-867.

Hanasaki Y., Ogawa S. and Fukui S. 1994. The correlation between active oxygen scavenging and antioxidative effects of flavonoids. Free Radical Biology and Medicine 16, 845-850.

Horzic D., Komes D., Belscak A., Ganic K.K., Ivekovic D. and Karlovic D. 2009. The composition of polyphenols and methylxantine in teas and herbal infusions. Food Chemistry 115, 441-448.

Jeu-Ming P.Y., Jun-Yun W., Hui-Hsueh C. and Ji-Yuan L. 2015. Effects of Temperature and Water Steeping Duration on Antioxidant Activity and Caffeine Content of Tea. MC-Transaction on Biotechnology 7, 22-32.

Jun X., Deji S., Ye L. and Rui Z. 2011. Comparison of in vitro antioxidant activities and bioactive components of green tea extracts by different extraction methods. International J. of Pharmaceutics 408, 97-101.

Khan A.A. and Alzohairy M.A. 2011. Hepatoprotective effects of camel milk against $\mathrm{CCl}_{4}$ induced hepatotoxicity in rats. Asian J. of Biochemistry 6, 171-180.

Kim H.S., Quon M.J. and Kim J.A. 2014. New insights into the mechanisms of polyphenols beyond antioxidant properties; lessons from the green tea polyphenol, epigallocatechin 3gallate. Redox Biology 2, 187-195.

Koo M.W. and Cho C.H. 2004. Pharmacological effects of green tea on the gastrointestinal system. European J. Pharmacology 500, 177185.

Lin S.D., Liang C.H., Liu E.H. and Mau J.L. 2010. Antioxidant properties of water extracts from parching green tea. J. of Food Biochemistry 34, 477-500.

Long L.H., Lan A.N.B., Hsuan F.T.Y. and Halliwell B. 1999. Generation of hydrogen peroxide by "antioxidant" beverages and the effect of milk addition. Is cocoa the best beverage. Free Radical Research 31, 67-71.

Malloy H.T. 1937. The determination of bilirubin with the photoelectric colorimeter. The J. of Biochemistry 112, 481-491.
Manzocco L., Anese M. and Nicoli M.C. 1998. Antioxidant properties of tea extracts as affected by processing. LWT- Food Sci. and Technology 31, 694-698.

Milašienè R., Sawicka K., Kornyšova O., Ligor M. and Buszewski B.M. 2007. Evaluation of antioxidant activity of green and black tea $(\mathrm{Ca}$ mellia sinensis) and rooibos (Aspalathus linearis) tea extracts by means of HPLC with reaction detector. Ars Separatoria Acta 5, 27- 33.

Namal Senanayake S.P.J. 2013. Green tea extract: Chemistry, antioxidant properties and food applications. J. of Functional Foods 5, 1529-1541.

Ng T.P., Aung K.C., Feng L., Feng L., Nyunt M.S. and Yap K.B. 2014. Tea consumption and physical function in older adults: a crosssectional study. The J. of Nutrition and Health Aging 18, 161-166.

Niederländer H.A.G., Van Beek T.A., Bartasiute A. and Koleva I.I. 2008. Antioxidant activity assays on-line with liquid chromatography. $\mathbf{J}$. of Chromatography 1210, 121-134.

Nor Qhairul Izzreen M.N. and Mohd Fadzelly A.B. 2013. Phytochemicals and antioxidant properties of different parts of Camellia sinensis leaves from Sabah Tea Plantation in Sabah, Malaysia. International Food Research J. 20, 307-312.

Ohkawa H., Ohishi N. and Yagi K. 1979. Assay for lipid peroxides in animal tissues by thiobarbituric acid reaction. Anal Biochemistry 95, 351-358.

Ong C.B. and Annuar M.S.M. 2017. Polyphenolic composition and in vitro antioxidant activities of native- and tannase-treated green tea extracts. International J. of Food Sci. and Technology 52, 1-9.

Oyaizu M. 1986. Studies on product of browning reaction prepared from glucose amine. Japanese J. of Nutrition 44, 307-315.

Philip G. Reeves, Forrest $H$. Nielsen and George C. Fahey 1993. Final report of the American Institute of Nutrition Ad Hoc Writing Committee on Reformulation of the AIN-76A Rodent Diet. The Journal of Nutrition 123, 1939-1951.

Piyanete C., Meechai P. and Nakbanpotecc W. 2009. Antioxidant activities and phenolic contents of extracts from Salvinia molesta and Eichornia crassipes. Research J. of Biological Sci. 4, 1113-1117.

Recknagel R.O., Glende E.A., Dolak J.A. and Waller R.L. 1989. Mechanisms of carbon tetrachloride toxicity. Pharmacology and Therapeutics 43, 139-154. 

Extract and Its Capability to Retardation of Rats Liver Cirrhosis

Rouanet J.M., Kelly D., Daniele D.R., Cyril A., Gina B., Jean-Paul C., Michael E.J.L. and Alan C. 2010. Berry juices, teas, antioxidants and the prevention of atherosclerosis in hamsters. Food Chemistry 118, 266-271.

Salah N., Miller N.J., Paganga G., Tijburg L., Bolwell G.P. and Rice-Evans C. 1995. Polyphenolic flavanols as scavengers of aqueous phase radicals and as chain-breaking antioxidants. Archives of Biochemistry and Biophysics 322, 339-346.

SAS, 2000. SAS/STAT User's guide Release 8.01 Ed. SAS Institute Inc., Cary NC, USA.

Schermer S. 1967. The blood morphology of laboratory animals (Davis F.A. ed.) $3^{\text {ed }}$. pp.10-42, Davis Co. Pub., Philadelphia, U.S.A.

Sheikhzadeh N. 2011. Immunodulatory effects of decaffeinated green tea (Camellia sinensis) on the immune system of rainbow trout (Oncorhynchus mykiss). Fish and Shellfish Immunology 31, 1268-1269.

Shen C.L., Chyu M.C., Yeh J.K., Zhang Y., Pence B.C. and Felton C.K. 2012. Effect of green tea and Tai Chi on bone health in postmenopausal osteopenic women: a 6-month randomized placebo controlled trial. Osteoporosis International 23, 1541-1552.

Shishikura Y. and Khokhar S. 2005. Factors affecting the levels of catechins and caffeine in tea beverage: estimated daily intakes and antioxidant activity. Journal of the Science and Food Agriculture 85, 2125-2133.

Sigma Plot Program 2014. Version 13.0, Build 13.0.0.83, Systat Software Inc. LEAD TOOLS, DUNDAS SOFTWARE Ltd., WP cubed Gmbh, Germany.

Singal A., Tirkey N., Pilkhwal S. and Chopra K. 2006. Green Tea (Camellia sinensis) Extract Ameliorates Endotoxin Induced Sickness Behavior and Liver Damage in Rats. Phytother. Research 20, 125-129.

Sun C., Wang J.W., Fang L., Gao X.D. and Tan R.X. 2004. Free radical scavenging and antioxidant activities of EPS2, an exopolysaccharide produced by a marine filamentous fungus Keissleriella sp. YS 4108. Life Sci., 75, 1063-1073.

Tomata Y., Kakizaki M., Nakaya N., Tsuboya T., Sone T. and Kuriyama S. 2012. Green tea consumption and the risk of incident functional disability in elderly Japanese: the Ohsaki Cohort 2006 Study. The American J. of Clinical Nutrition 95, 732-739.

Velayutham P., Babu A. and Liu D. 2008. Green tea catechins and cardiovascular health: an update. Current Medicinal Chemistry 15, 1840-1850.

Vey Sin, U. 2005. Encyclopedia healing tea. Neva, Sankt-Peterburg, 320 p. (in Russian). Veretinskaya, E. 2011. Application of digyrdroquercetine for milk shelf life extension. Pererabotka moloka 4, 44 (in Russian).

Vieira Senger A.E., Schwanke C.H., Gomes I. and Valle Gottlieb M.G. 2012 Effect of green tea (Camellia sinensis) consumption on the components of metabolic syndrome in elderly. The J. of Nutrition and Health Aging 16, 738742.

Wang Y., Li Y.Y., Nie Y.Q., Zhou Y.J., Cao C.Y. and $X u$ L. 2013. Association between metabolic syndrome and the development of nonalcoholic fatty liver disease. Experimental and Therapeutic Medicine 6, 77-84.

Young D.S. 1995. Effects of drugs on Clinical Lab. Tests, $4^{\text {th }}$ ed. AACC Press.

Zhang D. and Hamauzu Y. 2004. Phenolics, ascorbic acid, carotenoids and antioxidant activity of broccoli and their changes during conventional and microwave cooking. Food Chemistry 88, 503-509.

Zhang Y., Li Q., Xing H., Lu X., Zhao L., Qu K. and Bi K. 2013. Evaluation of antioxidant activity of ten compounds in different tea samples by means of an on-line HPLC-DPPH assay. Food Research International 53, 847-856.

Zielinski A.A.F., Granato D., Alberti A., Nogueira A., Demiate I.M. and Haminiuk C.W.I. 2015. Modelling the extraction of phenolic compounds and in vitro antioxidant activity of mixtures of green, white and black teas ( $\mathrm{Ca}$ mellia sinensis L. Kuntze). J. of Food Sci. and Technology, 52, 6966-6977.

Zimmerman H.J., Kodera Y. and West M. 1965. Effects of carbon tetrachloride poisoning on the plasma levels of cytoplasmic and mitochondrial enzymes in animals with nutritional fatty metamorphosis. J. of Laboratory and Clinical Medicine 66, 324-333. 


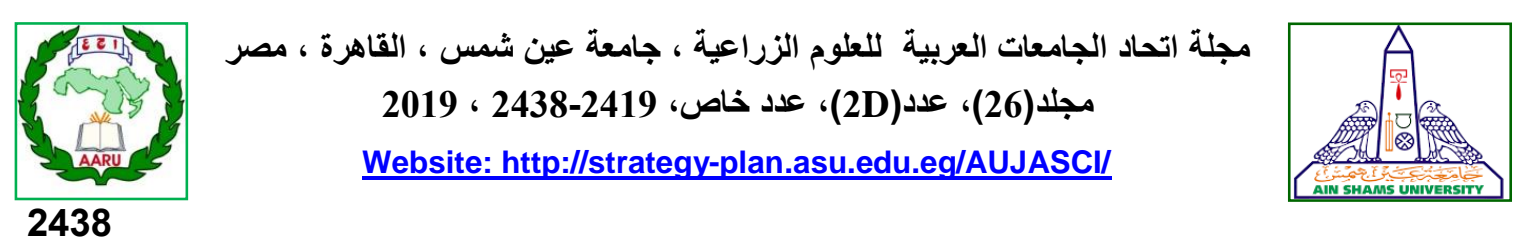

النشاط المضاد للأكسدة والثققوق الحرة للمستخلص المائى للثاى الأخضر وقدرته على تأخير تليف الكبد فى الفئران

[178]

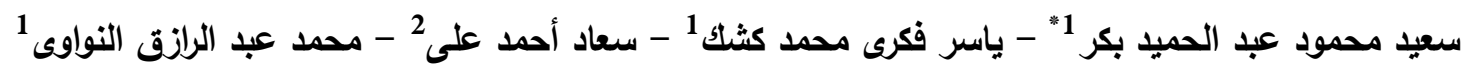

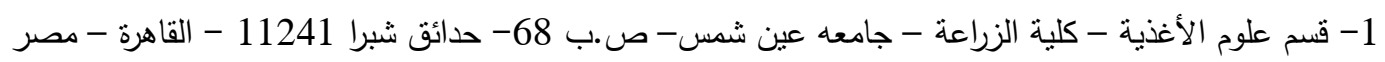

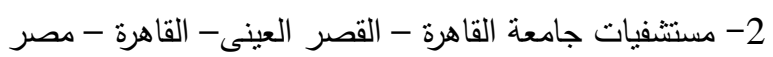

*Corresponding author: SaiedMbakr@gmail.com

Received 14 June, 2018

Accepted 30 July, 2018

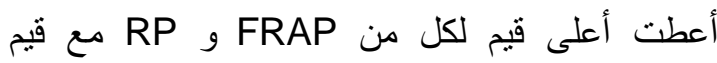
2.566 و 1.678 مع معامل ارتباط كان 0.9780

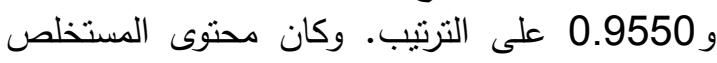
من الفينولات والفلافونويدات الكلية 81.2 ملجم مكافئ حمض الجاليك و33.5 ملجم مكافئ كيوريسيتين لكل

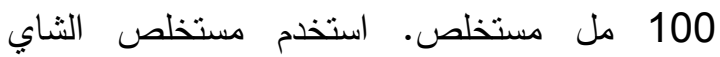
الأخضر المحضر عند الظروف المنلى في معاملة

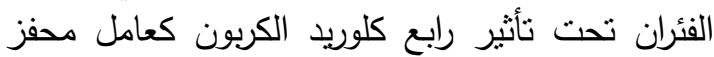

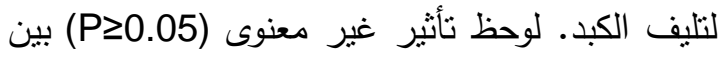
المجموعة الضابطة والمجموعة المعاملة برابع كلوريد

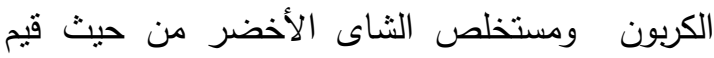
البروتين الكلى والألبيومين. على الجانب الألى الأنر فإن كل من قيم البروتين الكلى والألبيومين حدث لهابل لها إنخفاض الاض

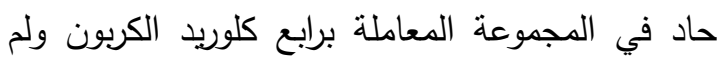

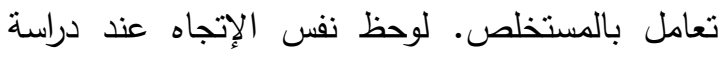

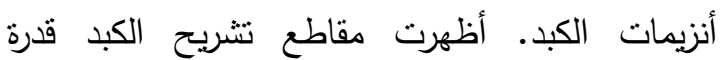

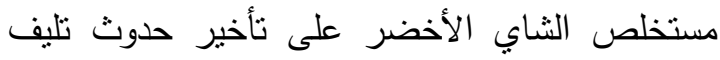
الكبد في الفئران المعاملة برابع كلوريد الكربون.

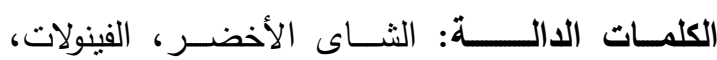

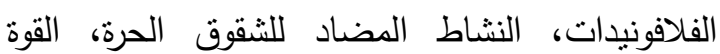

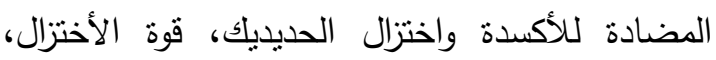

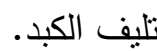

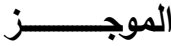

هدفت هذه الدراسة الى تقدير الظروف المتلى الفي

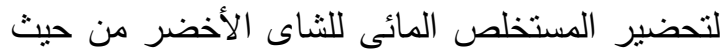

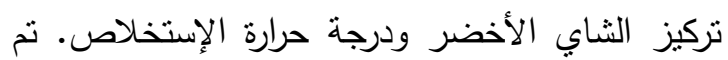

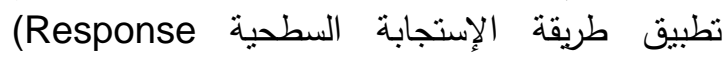
surface methodology) اللثقوق الحرة (RSA)، القوة المضادة للأكسدة

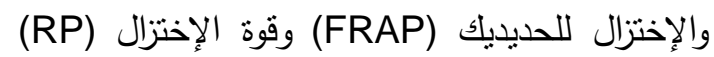
لمستخلص الثابي الأخضر المحضر ـ أيضا تم دراسة الإنزال

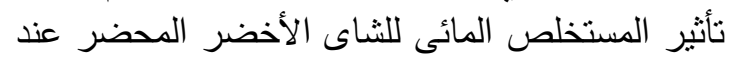

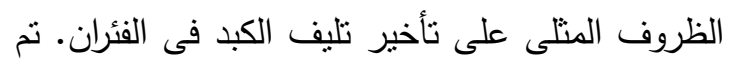

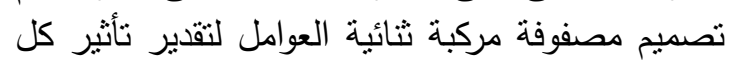

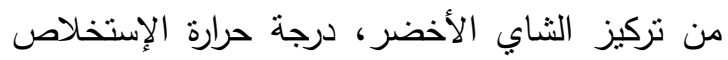

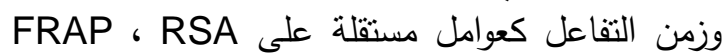

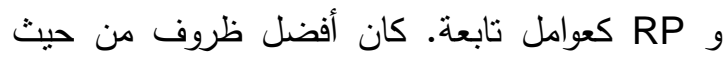

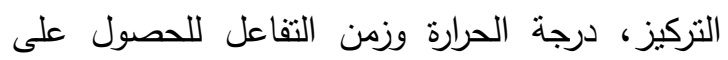

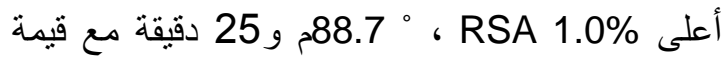

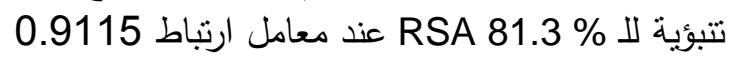
مقارنة بال BHT والذى كان له له قيمة RSA

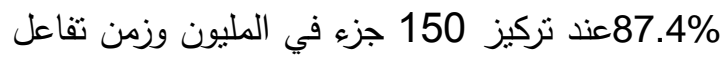
30 دقيقة. نفس قيم التركيز ودرجة الحرارة المتتبأ بها سابقا عند تحضير المستخلص المائى للثاى الأخضر 